\title{
Past temperature reconstructions from deep ice cores: relevance for future climate change
}

\author{
V. Masson-Delmotte ${ }^{1}$, G. Dreyfus ${ }^{1}$, P. Braconnot ${ }^{1}$, S. Johnsen ${ }^{2}$, J. Jouzel ${ }^{1}$, M. Kageyama ${ }^{1}$, A. Landais ${ }^{1,3}$, \\ M.-F. Loutre ${ }^{4}$, J. Nouet ${ }^{1}$, F. Parrenin ${ }^{5}$, D. Raynaud ${ }^{5}$, B. Stenni ${ }^{6}$, and E. Tuenter ${ }^{7}$ \\ ${ }^{1}$ Laboratoire des Sciences du Climat et de l'Environnement, IPSL/CEA-CNRS-UVSQ, Bat 701 L'Orme des Merisiers, CEA \\ Saclay, 91191 Gif-sur-Yvette cédex, France \\ ${ }^{2}$ Niels Bohr Institute, University of Copenhagen, Copenhagen, Denmark \\ ${ }^{3}$ Institute of Earth Sciences, Hebrew University, Givat Ram, Jerusalem, Israel \\ ${ }^{4}$ Institut d'Astronomie et de Géophysique Georges Lemaitre, Université Catholique de Louvain, Louvain-la-Neuve, Belgique \\ ${ }^{5}$ Laboratoire de Glaciologie et Géophysique de l'Environnement, CNRS-UJF, BP 9638402 Saint Martin d'Heres Cedex, \\ France \\ ${ }^{6}$ Department of Geological, Environmental and Marine Sciences, University of Trieste, Trieste, Italy \\ ${ }^{7}$ Department of Earth Sciences, University of Utrecht, Utrecht, The Netherlands
}

Received: 10 May 2006 - Published in Clim. Past Discuss.: 12 July 2006

Revised: 16 October 2006 - Accepted: 17 October 2006 - Published: 26 October 2006

\begin{abstract}
Ice cores provide unique archives of past climate and environmental changes based only on physical processes. Quantitative temperature reconstructions are essential for the comparison between ice core records and climate models. We give an overview of the methods that have been developed to reconstruct past local temperatures from deep ice cores and highlight several points that are relevant for future climate change.

We first analyse the long term fluctuations of temperature as depicted in the long Antarctic record from EPICA Dome $\mathrm{C}$. The long term imprint of obliquity changes in the EPICA Dome $\mathrm{C}$ record is highlighted and compared to simulations conducted with the ECBILT-CLIO intermediate complexity climate model. We discuss the comparison between the current interglacial period and the long interglacial corresponding to marine isotopic stage 11, 400 kyr BP. Previous studies had focused on the role of precession and the thresholds required to induce glacial inceptions. We suggest that, due to the low eccentricity configuration of MIS 11 and the Holocene, the effect of precession on the incoming solar radiation is damped and that changes in obliquity must be taken into account. The EPICA Dome $\mathrm{C}$ alignment of terminations I and VI published in 2004 corresponds to a phasing of the obliquity signals. A conjunction of low obliquity and minimum northern hemisphere summer insolation is not found in the next tens of thousand years, supporting the idea of an unusually long interglacial ahead.
\end{abstract}

Correspondence to: V. Masson-Delmotte

(valerie.masson@cea.fr)
As a second point relevant for future climate change, we discuss the magnitude and rate of change of past temperatures reconstructed from Greenland (NorthGRIP) and Antarctic (Dome C) ice cores. Past episodes of temperatures above the present-day values by up to $5^{\circ} \mathrm{C}$ are recorded at both locations during the penultimate interglacial period. The rate of polar warming simulated by coupled climate models forced by a $\mathrm{CO}_{2}$ increase of $1 \%$ per year is compared to ice-core-based temperature reconstructions. In Antarctica, the $\mathrm{CO}_{2}$-induced warming lies clearly beyond the natural rhythm of temperature fluctuations. In Greenland, the $\mathrm{CO}_{2}$-induced warming is as fast or faster than the most rapid temperature shifts of the last ice age. The magnitude of polar temperature change in response to a quadrupling of atmospheric $\mathrm{CO}_{2}$ is comparable to the magnitude of the polar temperature change from the Last Glacial Maximum to present-day. When forced by prescribed changes in ice sheet reconstructions and $\mathrm{CO}_{2}$ changes, climate models systematically underestimate the glacial-interglacial polar temperature change.

\section{Introduction}

The polar regions play a key role in the global climate system. They represent the "cold points" where the local net radiative loss is partly compensated by the ocean and atmosphere heat (and moisture) transports. The polar oceans are involved in the global oceanic circulation through the formation of surface cold and dense waters. Changes in sea-ice

Published by Copernicus GmbH on behalf of the European Geosciences Union. 

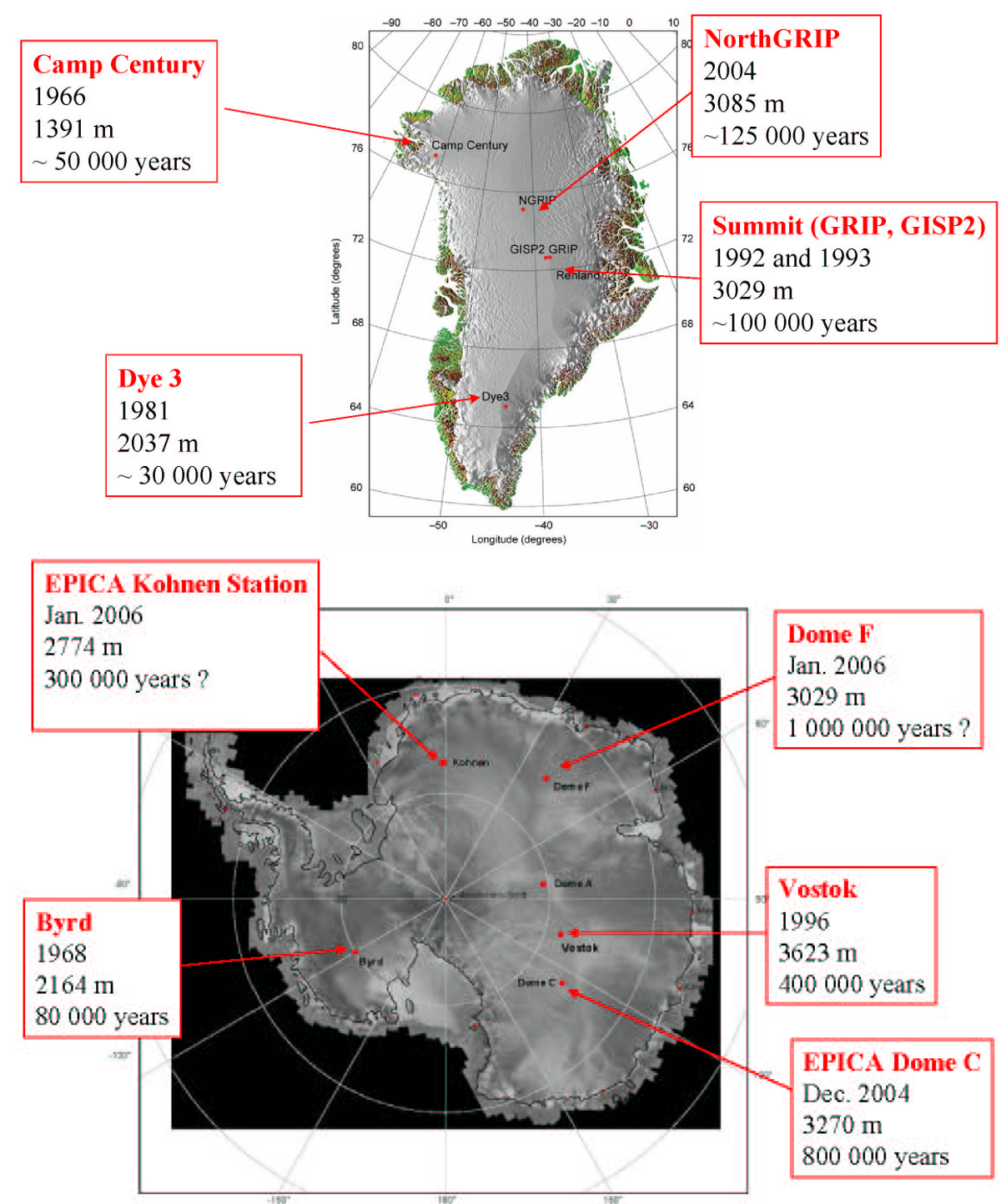

Fig. 1. Maps of Greenland and Antarctica showing first and most recent deep ice core sites. For each drilling site are indicated the name of the deep drilling, the year of drilling completion, the final depth and an estimate of the length of the recovered climate and environmental records.

have been showed to have impacts on the formation of these deep and salty waters, but also to influence the hemispheric atmospheric circulation (Dethloff et al., 2006; Yuan and Martinson 2000; Chiang and Bitz, 2005). Atmospheric circulation has been shown to link polar locations with other latitudes (Liu et al., 2004; Marshall et al., 2001) and southern latitudes (Guo et al., 2004; Yuan, 2004; Turner, 2004). Several processes at play in polar regions are involved in climate feedbacks: dynamical transport effects; atmospheric content of water vapour (Solomon, 2006); polar cloud cover; surface snow and ice albedo; sea-ice extent (Holland and Bitz, 2003). Polar regions north and south are also involved in the carbon cycle via the role of the southern ocean and deep ocean circulation (Kohler et al., 2005) and the soil carbon storage in permafrost areas (Davidson and Janssens, 2006). Today, some areas of the polar regions experience the largest observed warming over the instrumental records (IPCC, 2001). There is therefore a strong interest to obtain past temperature reconstructions from these polar regions.

The Greenland and Antarctic polar ice sheets represent $\sim 70 \%$ of the freshwater on Earth. Because of their volume and time constants, these ice sheets are the slow components of the climate system. It is for instance suggested that the average age of ice inside the Greenland ice sheet is $41 \pm 2 \mathrm{kyrs}$ (respectively, $125 \pm 5 \mathrm{kyrs}$ and $44 \pm 3 \mathrm{kyrs}$ for the East and West Antarctic ice sheets) (Lhomme et al., 2005). Huge 
uncertainties remain on their vulnerability to future climate changes, and therefore on their contribution to the ocean water budget and to the global sea-level changes on time scales of centuries to millennia (Alley et al., 2005). On the central parts of the Greenland and Antarctic ice sheets, the slow burial of successive snowfall preserved under cold conditions (typically annual mean temperatures at $-30^{\circ} \mathrm{C}$ at the summit of the Greenland ice cap, below $-50^{\circ} \mathrm{C}$ on the East Antarctic plateau above $3000 \mathrm{~m}$ elevation) provides archives of past climate and environment. Ice cores are usually described as unique paleoclimate archives because they provide information not only on past local changes (temperature, accumulation) but also relevant for other areas (e.g. aerosol content of the atmosphere) (Wolff, 2006) and even at the global scale (greenhouse gases preserved in the air trapped in the ice) (Siengenthaler et al., 2005; Spahni et al., 2005, and references herein). Ice cores are also unique in so far as they provide past temperature reconstructions based on physical processes, differing from many other paleoclimatic archives that involve biological processes.

Today, three different methods are available to assess past polar temperature changes. (i) The stable isotopic composition of water molecules is classically used to estimate continuously past temperature changes, because the degree of distillation of an air mass, and therefore the final loss of heavy water molecules, is at first order controlled by its cooling (Dansgaard, 1964). (ii) Owing to the diffusion of heat from the surface to the depth of the ice sheets, partial imprints of past temperature changes can be found in the temperature profiles of boreholes (Dahl-Jensen and Johnsen, 1986; Dahl-Jensen et al., 1998). The dating of the ice cores provides an independent assessment of these temperature reconstructions, through the relationship linking polar atmospheric temperatures and the atmospheric moisture holding capacity (Parrenin et al., 2001). (iii) When abrupt temperature changes occur, a molecular diffusion of gas inside the firn occurs until temperature diffusion restores a stable depth temperature gradient in the upper part of the ice sheets (Severinghaus et al., 1998; Landais et al., 2004). This thermal gas diffusion process allows an estimation of rapid temperature changes based on the past fluctuations of the isotopic composition of gases which are considered as constant in the atmosphere $\left(\delta^{15} \mathrm{~N}, \delta^{40} \mathrm{Ar}\right)$. Because our methods are based on relatively well understood physical processes, models of atmospheric circulation and isotopic or firn physics can be used to assess the uncertainties of the temperature estimates (Jouzel et al., 1997, 2003; Werner et al., 2001; Landais et al., 2004). Quantitative temperature reconstructions from deep ice cores offer the possibility to analyse the relationships between polar temperature changes and climate forcings, and discuss past climate sensitivity (Genthon et al., 1987). They also offer the possibility to test the local response of climate models to prescribed forcings and to compare the magnitude and pacing of past climate changes, with those that would result from increased atmospheric $\mathrm{CO}_{2}$ levels.
In this paper, we focus on past temperature changes from the longest ice core temperature records recently made available: the EPICA Dome $\mathrm{C}$ ice core, drilled at $75^{\circ} \mathrm{S}$ in central East Antarctica (EPICA-community-members, 2004) and the NorthGRIP ice core drilled at $75^{\circ} \mathrm{N}$ in Greenland (NorthGRIP-community-members, 2004), which respectively extend the unperturbed ice core climate records back to 740 and 123 kyrs (Figs. 1 to 3). In Sect. 2, we present the methods used to extract temperature signals from deep ice cores and the climate simulations used in the next sections. Section 3 is dedicated to the long term EPICA record and its relationship with the orbital parameters of the Earth. We discuss the specific imprint of obliquity variations on Antarctic temperature changes, as well as the comparison between the current interglacial period and an older long interglacial period (marine isotopic stage MIS11, $400 \mathrm{ka} \mathrm{BP}$ ), which was suggested to be an "orbital analogue (Berger and Loutre, 2002). In Sect. 4, we review the orders of magnitude and pacing of surface air temperature changes reconstructed from Antarctic and Greenland ice core estimates. We finally compare the magnitude and rate of change of polar temperature change simulated by coupled ocean-atmosphere models in response to increased $\mathrm{CO}_{2}$ levels (simulations conducted for the Fourth Assessment Report of the Intergovernmental Panel for Climate Change) with those simulated under Last Glacial Maximum boundary conditions (simulations conducted for the Paleoclimate Modelling Intercomparison Project) and with the reconstructions.

\section{Methods}

\subsection{Temperature reconstructions from deep ice core sites}

\subsubsection{Methods based on stable water isotopes}

Past temperature changes have originally been quantified from the stable isotope composition of water in ice cores $\left(\delta D\right.$ or $\left.\delta^{18} \mathrm{O}\right)$ which is measured continuously on deep ice cores with high precision using mass spectrometers (respectively 0.5 and 0.05 ). Empirically, it has long been observed that the isotopic content of surface snow is linearly related to the surface temperature (Dansgaard, 1964; Lorius and Merlivat, 1977). Isotopic models following the distillation of air masses along an idealised trajectory are used to disentangle the processes involved in the spatial isotope-temperature slope. Evaporation fractionation depending on surface conditions (sea surface temperature, relative humidity, wind speed) controls the isotopic composition of the atmospheric water vapour (Ciais and Jouzel, 1994). Along the air mass trajectory, an isolated air parcel undergoes a progressive cooling. The fractionation taking place during condensation induces a progressive loss of heavy isotopes in the water vapour from the source areas to the coldest places. As a result of this atmospheric distillation, the main control of the polar regions 
isotopic composition is the difference between the source and site temperatures.

Past changes in evaporation conditions or atmospheric transport may induce biases on the temperature reconstructions based on $\delta D$ or $\delta^{18} \mathrm{O}$. In principle, the main control on the isotopic composition of snowfall is not the surface temperature but the temperature at the height of condensation. It is often assumed that, in central Antarctica, the condensation temperature is similar to the temperature in the inversion layer, and is linearly related to the surface temperature. In principle, such a hypothesis should not apply for coastal Antarctica or Greenland where convective activity occurs at least episodically. Therefore, changes in the the vertical temperature profiles may also alter past temperature reconstructions. Obviously, the isotopic composition of ice only records past temperatures when snowfall occurs; changes in the seasonality of precipitation may also induce biases on temperature reconstructions (Krinner et al., 1997). Finally, it has been suggested that post deposition effects may alter the isotopic composition of snowfall in very dry places (Neumann et al., 2005).

Some artefact sources can be quantified based on simulations conducted with atmospheric general circulation models equipped to explicitly calculate the different stable isotopes of water (Joussaume et al., 1984). Simulations of the Last Glacial Maximum, 21000 years ago, were performed by such iso-AGCMs (Werner et al., 2001).

\subsubsection{Continuous temperature reconstruction for Antarc- tica}

It has been showed that, in central east Antarctica, the relationship between surface snow and temperature observed today remains valid for the LGM (Jouzel et al., 2003). The validity of this method is also verified from the dating of the deep ice cores, which uses a modelling of the relationship between stable isotopes, temperature and accumulation together with flow models to provide the age scale of the ice cores. Inverse dating methods applied for several central east Antarctic deep ice cores have confirmed the validity of the isotope-based reconstructions within 20 to $30 \%$ (EPICA-community-members, 2004; Parrenin et al., 2001, 2004; Watanabe et al., 2003).

In the rest of this paper, the Antarctic temperature reconstructions will be discussed based on the continuous $\delta D$ profile measured on EPICA Dome C ice core (Fig. 3), corrected for the global seawater isotopic composition (Bintanja et al., 2005; Liesicki and Raymo, 2005) and transferred to past temperatures using the observed spatial slope of 6.04 per ${ }^{\circ} \mathrm{C}$ (Delmotte, 1997; Lorius and Merlivat, 1977). More sophisticated methods have been applied for east Antarctic sites taking advantage of the combined measurements of $\delta D$ and $\delta^{18} \mathrm{O}$ of the same samples, using the deuterium excess parameter $\left(\mathrm{d}=\delta \mathrm{D}-8 \delta^{18} \mathrm{O}\right)$ in order to correct past temperature reconstructions from changes in evaporation conditions
(Cuffey and Vimeux, 2001; Stenni et al., 2003, 2001). However, because the full deuterium excess profile is not available yet for EPICA Dome $\mathrm{C}$ ice core, we use the classical temperature reconstruction method and a maximum $30 \%$ uncertainty on the reconstructed temperature.

The next sections rely on the temperature changes reconstructed at Dome C, which are extremely similar to those derived from other inland East Antarctica drilling sites such as Vostok or Dome Fuji (Watanabe et al., 2003). Figure 3 displays this profile on its published EDC2 age scale (EPICAcommunity-members, 2004) as well as on a preliminary age scale where the precession signature on the EPICA air $\delta^{18} \mathrm{O}_{\mathrm{atm}}$, a marker of global ice volume and productivity, (Bender et al., 1985) has been used to improve the dating of MIS13 to MIS15 (Dreyfus et al., 2006 ${ }^{1}$ ). For this time period, this revised age scale is in better agreement with the dating of marine records (Liesicki and Raymo, 2005) and preserves over the oldest section the $\mathrm{CO} 2$-deuterium phase lags observed over the past climatic cycles (Siengenthaler et al., 2005). We estimate a $20 \%$ uncertainty associated with the glaciological age scale (Parrenin, 2006 ${ }^{2}$ ) on the duration of selected climatic changes (back to MIS11) discussed in Sect. 3 in terms of pacing of temperature changes.

\subsubsection{Continuous temperature reconstruction for Green- land}

The situation is more contrasted for central Greenland, where atmospheric general circulation models simulate a much larger glacial precipitation decrease in winter than in summer, resulting in a change of the precipitation-weighted temperature and annual mean snowfall isotopic composition (Krinner et al., 1997; Krinner and Werner, 2003). This seasonality effect leads to a dramatic underestimation of glacialinterglacial temperature magnitude when using only the stable isotopic composition of snow as proxy (Jouzel et al., 1997).

In central Greenland, the inversion of the borehole temperature profile allows an assessment of the magnitude of Greenland temperature changes during the past decades, centuries, maximum warmth in the Holocene, and LGM cooling (DahlJensen et al., 1998; Cuffey et al., 1992). This method shows that the glacial to Holocene isotope-temperature slope is twice as small $\left(0.33 \delta^{18} \mathrm{O}\right.$ per $\left.{ }^{\circ} \mathrm{C}\right)$ as today's spatial isotopetemperature slope $\left(0.67 \delta^{18} \mathrm{O}\right.$ per $\left.{ }^{\circ} \mathrm{C}\right)$.

Another paleotemperature method has been developed specifically for quantifying abrupt temperature changes in Greenland. In the case of an abrupt temperature change, the firn undergoes a transient temperature gradient until the diffusion of temperature into snow and ice erases the transient imbalance. Under a vertical temperature gradient, the

\footnotetext{
${ }^{1}$ Dreyfus, G., Parrenin, F., Lemieux, B., et al: An optimal chronology for the EPICA Dome C ice core over MIS 11-15 using the isotopic composition of trapped air, in preparation, 2006.

2 Parrenin, F.: in preparation, 2006.
} 
gases present inside the firn (which can be seen as a porous medium) undergo a thermal fractionation, with the heaviest species being concentrated at the coldest end. The analysis of species whose isotopic ratios are constant in the atmosphere over hundreds of thousands of years, such as $\delta^{40} \operatorname{Ar}$ or $\delta^{15} \mathrm{~N}$, can be combined with firn modelling to provide estimates of past abrupt temperature changes. This method, initially developed by (Severinghaus et al., 1998), has been applied to several rapid events in various Greenland ice cores (GISP2, GRIP and NorthGRIP) such as abrupt temperature changes during the last deglaciation, (Severinghaus and Brook, 1999) and series of Dansgaard-Oeschger events (Huber et al., 2006; Landais et al., 2004, 2005; Lang et al., 1999) and one event in Antarctica ${ }^{3}$. The method has revealed that the temporal temperature-isotope slope was again about twice as small as the spatial isotope-temperature slope during abrupt events, characterised by amplitudes ranging between 8 to $16 \pm 3^{\circ} \mathrm{C}$ (see Fig. 2).

In order to assess the magnitude of Greenland temperature changes continuously, together with the pacing of their fluctuations, we have used the GRIP ice core temperature reconstruction published in Masson-Delmotte et al. (2005). This method uses the borehole and gas fractionation constraints to model changes in seasonality and reconstruct continuously past temperature changes from water stable isotope profiles, without however explicit correction for ice sheet elevation changes (Cuffey and Clow, 1997). Using the NorthGRIP ice core record, we have therefore complemented the GRIP temperature reconstruction back to 123000 years using this simple change of slopes, after correction for seawater isotopic composition (Liesicki and Raymo, 2005; Bintanja et al., 2005). Pieces of ice identified in the bottom sections of GRIP and GIPS2 to be from MIS5e by comparison of their air composition with that preserved in Antarctic ice showed similar ranges of $\delta^{18} \mathrm{O}$ as recorded in NorthGRIP (Landais et al., 2003). We estimate that these reconstructions are valid within $30 \%$ (this is due to the \pm 2.5 to $3^{\circ} \mathrm{C}$ uncertainty on the gas fractionation based reconstructions with amplitudes of 8 to $16^{\circ} \mathrm{C}$ ). To summarize, we use the Greenland ice core $\delta^{18} \mathrm{O}$ profile, which provides the shape and duration of climate events, and reconstruct past temperature changes which correspond to different slopes for cold and warm periods

\footnotetext{
${ }^{3}$ In Antarctica, the magnitude of the isotope anomaly is too weak to accurately deduce a change of temperature. However, the depth difference between the anomaly detected in the gas versus the ice phase is an indicator of the close-off depth, itself dependent on surface temperature.

Caillon, N., Severinghaus, J. P., Barnola, J.-M., Chappellaz, J., Jouzel, J., and Parrenin, F.: Estimation of temperature change and of gas age - ice age difference, $108 \mathrm{kyr}$ BP, at Vostok, Antarctica: J. Geophys. Res., 106, 31 893-31 901, 2001. checked that the closeoff depth obtained by this method for a single climate event is compatible with modelled based estimates, supporting a reliable use of stable isotopes of water to reconstruct past changes in Antarctic temperature within 20 to $30 \%$.
}

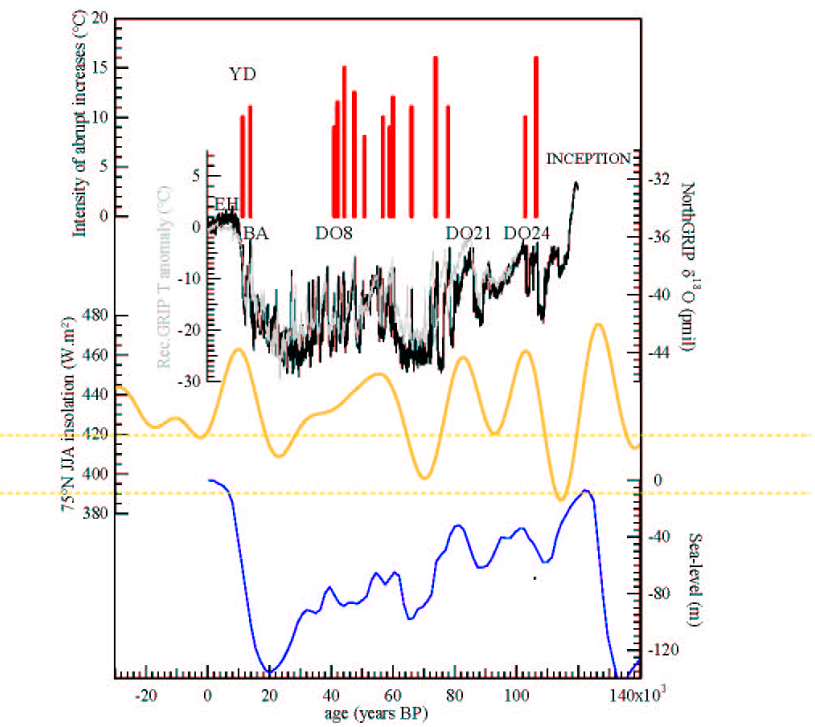

Fig. 2. NorthGRIP $\delta^{18} \mathrm{O}$ profile together with gas fractionation estimates of rapid temperature changes during rapid events. After Masson-Delmotte et al. (2005) with original data from NorthGRIPcommunity-members (2004); Huber et al. (2006); Landais et al. (2004); Severinghaus et al. (1998, 2003); Severinghaus and Brook (1999); Grachev and Severinghaus (2003). JJA $75^{\circ} \mathrm{N}$ insolation (orange line) is calculated after Berger and Loutre (1991). The global sea-level reconstruction (blue line) is from Waelbroeck et al. (2002).

(Masson-Delmotte et al., 2005). This method leads to temperature changes consistent with borehole and gas fractionation paleothermometry. We have used the ss09sea Greenland age scale (Johnsen et al., 2001), again associated with a $\sim 20 \%$ uncertainty in the duration of climatic events discussed in Sect. 3 (Rasmussen et al., 2006).

\subsubsection{Uncertainties on "warm" temperature reconstructions}

Neither for Greenland nor for Antarctica do we have any alternative paleothermometry method that has been applied for periods "isotopically" warmer than today such as the previous interglacial period (Marine Isotopic Stage MIS 5e). In the mid-Holocene, Greenland ice core stable isotopic data point to a $1.5^{\circ} \mathrm{C}$ multi-centennial warming above present-day (Masson-Delmotte et al., 2005), compared to 2 to $2.5^{\circ} \mathrm{C}$ inferred from the borehole temperature profiles (Dahl-Jensen et al., 1998; Cuffey and Clow, 1997). This fact suggests that past temperature reconstructions based on stable isotopes may be underestimated also during periods warmer than today. No simulation of MIS5e has been made available with an atmospheric general circulation model including the representation of water isotopic composition. We have therefore no objective means to assess the uncertainty of isotope-based temperature reconstructions during periods warmer than now. Changes in ice sheet elevation may also have occurred in Greenland (Cuffey and Marshall, 2000). 


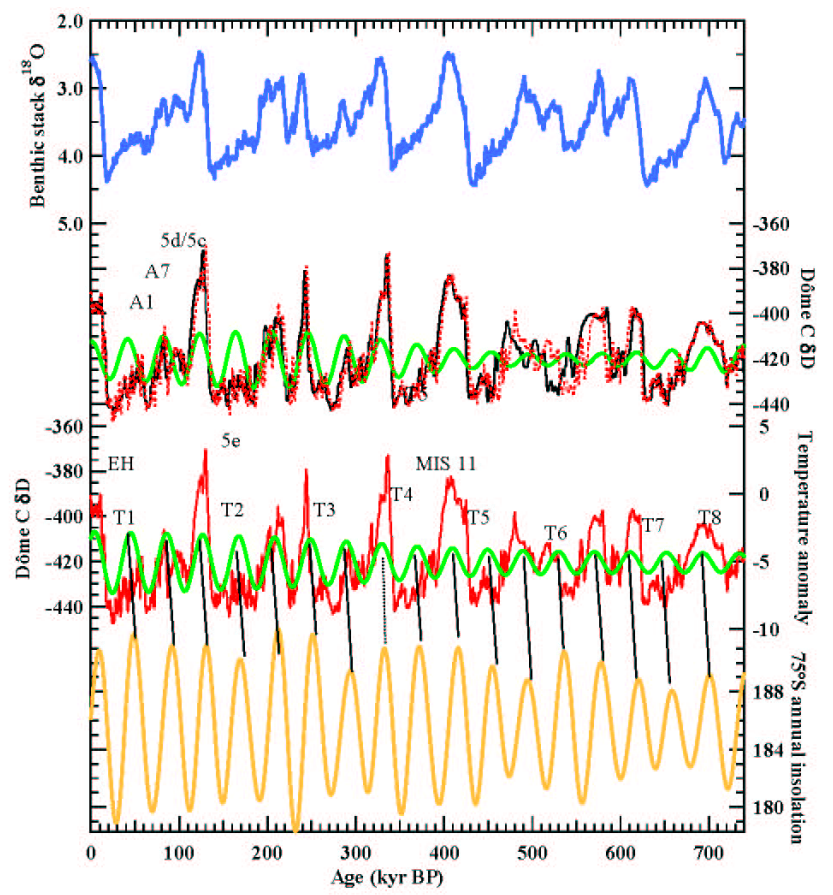

Fig. 3. Comparison of glacial-interglacial cycles recorded in a stack marine benthic $\delta^{18} \mathrm{O}$ records (Liesicki and Raymo, 2005) (blue) and in the deuterium ratio of EPICA Dome $\mathrm{C}$ ice core. The EPICA Dome $\mathrm{C}$ deuterium record is displayed on its initial EDC2 age scale (EPICA-community-members, 2004) (black line) as well as on a preliminary age scale based on the precession signal recorded in the air $\delta^{18} \mathrm{O}_{\text {atm }}$ composition (Dreyfus et al., 2006 ${ }^{1}$ ), in better agreement with the marine records (dashed and solid red lines). The range of corresponding temperature changes is displayed (left axis). The obliquity component of the deuterium records extracted using a Multi-Taper Method is displayed as a green line. Fluctuations of $75^{\circ} \mathrm{S}$ annual mean insolation, resulting from changes in obliquity, are also displayed (bottom panel) (Berger and Loutre, 1991).

In this paper, we apply for all past periods an uncertainty of $30 \%$ on past temperature reconstructions derived from stable isotope profiles. At the isotopic "maximum" of the NorthGRIP $\delta^{18}$ O record, about 123 kyrs ago, Greenland temperatures are derived to have been $\sim 5^{\circ} \mathrm{C}$ warmer than today (NorthGRIP-community-members, 2004) (Fig. 2). At the isotopic "maximum" of the EPICA $\delta \mathrm{D}$ record, about 125 to $130 \mathrm{kyrs}$ ago, east Antarctic temperatures are also derived to have been up to $\sim 5^{\circ} \mathrm{C}$ warmer than today (EPICAcommunity-members, 2004) (Fig. 3). Based on stable isotope profiles, the largest centennial warming recorded above present-day values is therefore estimated to reach $\sim 5^{\circ} \mathrm{C}$ at both poles.

\subsection{Climate modelling}

The EPICA reconstructions are analysed in Sect. 3 with a focus on the imprint of obliquity fluctuations on Antarctic temperatures. Simulations conducted with a model of intermediate complexity, ECBILT-CLIO, are used to describe the impact of idealised orbital configurations (extreme obliquity levels) (Tuenter et al., 2005) on surface temperatures, all other boundary conditions being kept to their present-day levels (vegetation, atmospheric composition, ice sheet topography...).

Greenland and Antarctic estimates of temperature changes from the Last Glacial Maximum to the present-day are compared in Sect. 4 to the result of simulations conducted with general circulation ocean-atmosphere-sea-ice models (including ECBILT-CLIO) within the Paleoclimate Modelling Intercomparison Project (PMIPII) (Harrison et al., 2002) (http://www-lsce.cea.fr/pmip2/, database version: April 2006) for the Last Glacial Maximum climate (LGM), 21000 years ago. In this case, the boundary conditions have been standardised and include changes in the atmospheric greenhouse gas composition, changes in the orbital parameters (with minor effects for the LGM), changes in land-sea and ice sheet topography (both with prescribed ice sheets and sea-level changes) (Peltier, 2004). Changes in dust load in the atmosphere and in vegetation are not included. In September 2005, five coupled model simulations were available on PMIP2 database and have been compared to ice core data in terms of polar amplification (Masson-Delmotte et al., 2006). These simulations are conducted as equilibrium simulations and cannot be used to derive the pacing of simulated changes.

In Sect. 4, we finally compare the magnitude and pacing of past temperature changes reconstructed from deep ice cores to the changes simulated by coupled ocean-atmosphere-seaice models in response to prescribed increases in atmospheric greenhouse gas levels. Standardised simulations with the same models as for PMIP2 and other models have been conducted for the Fourth Assessment Report of the Intergovernmental Panel for Climate Change within the Coupled Model Intercomparison Project CMIP (http://www-pemdi.llnl.gov/ projects/cmip/index.php). Here, we have analysed the final results of simulations where $\mathrm{CO}_{2}$ concentrations increase by $1 \%$ per year, until they reach a doubling of pre-industrial $\mathrm{CO}_{2}$ levels (over 70 years, $2 \times \mathrm{CO}_{2}$ experiments) or a quadrupling of pre-industrial $\mathrm{CO}_{2}$ levels (over 140 years, $4 \times \mathrm{CO}_{2}$ experiments). In both cases, $\mathrm{CO}_{2}$ levels where then stabilised over 150 years and model outputs were analysed during this stabilisation period (pseudo "equilibrium" response). Altogether, these simulations correspond to climate changes occurring over $\sim 120$ to 170 years and $\sim 190$ to 240 years after the start of $\mathrm{CO}_{2}$ increase respectively for $2 \times \mathrm{CO}_{2}$ and $4 \times \mathrm{CO}_{2}$ experiments, and have been used to compare the magnitude and pacing of anthropogenic $\mathrm{CO}_{2}$-induced climate change with the magnitude and pacing of past natural climate fluctuations (Sect. 3). 

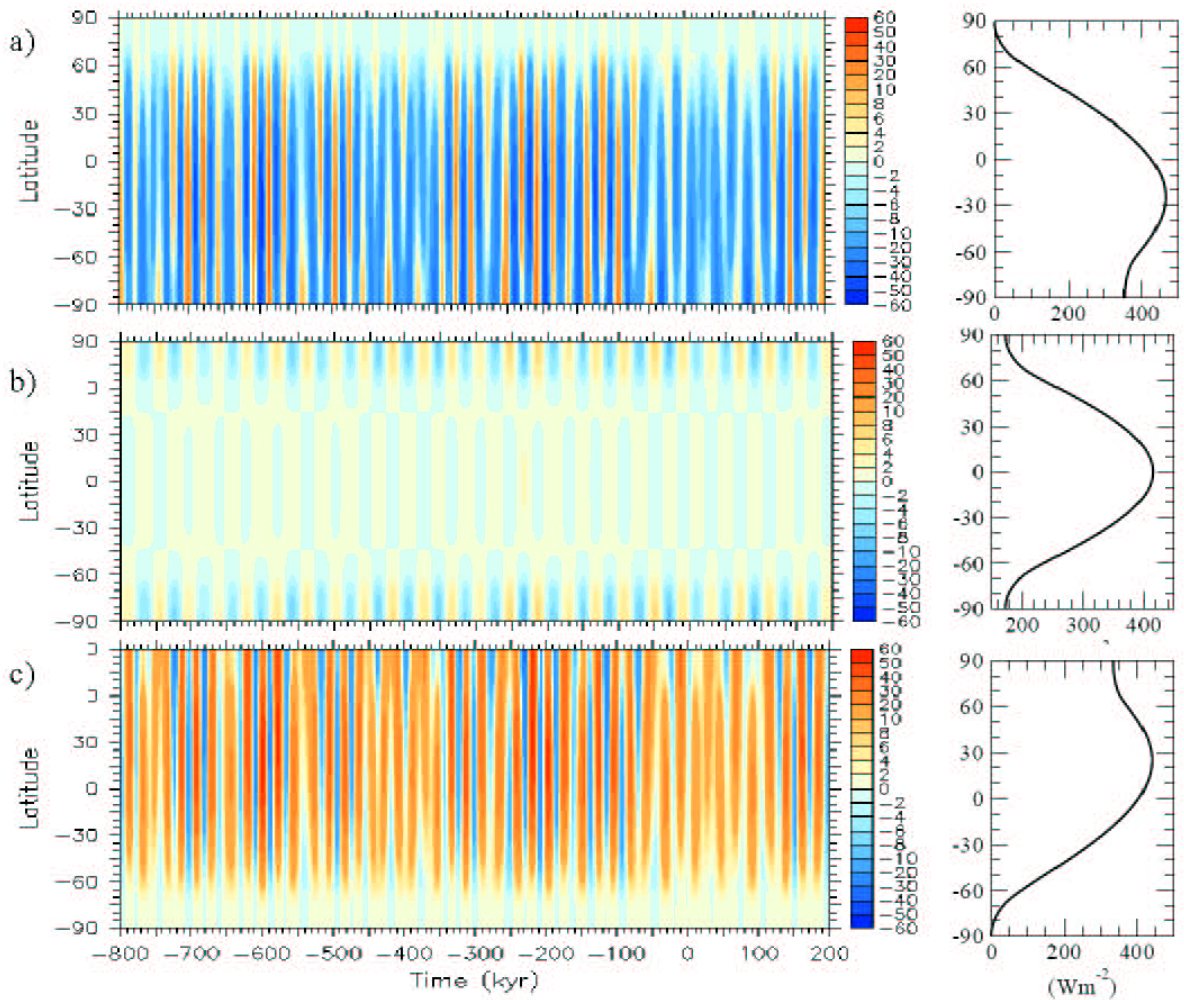

Fig. 4. Calculations of past ( -800 to $0 \mathrm{ka}$ ) and future ( 0 to $200 \mathrm{ka}$ ) changes in the latitudinal distribution of December-January-February (a), annual mean (b) and June-July-August (c) deviations (left) from the present-day (right) incoming solar radiation at the top of the atmosphere, in $\mathrm{W} / \mathrm{m}^{2}$.

\section{Imprint of obliquity on polar temperature records and relevance for the "analogy" between MIS11 and the current interglacial}

Because they strongly modulate the distribution of incoming solar radiation at the top of the atmosphere, the orbital parameters of the Earth are seen as the driving force for climate changes occurring on time scales longer than 10000 years (also called orbital time scales) (Milankovitch, 1941). A hierarchy of climate models has been used to analyse the relationships between orbital forcing and climate dynamics. Conceptual models have been used to analyse the non linear climate response (Claussen et al., 2002) and general circulation climate models (Braconnot, 2004) have been used to highlight the importance of climate feedbacks in the relationships between observed climate changes and orbital forcing. These climate feedbacks are related to changes in the water and carbon cycle and atmospheric greenhouse gas concentration (including water vapour), changes in the surface albedo associated with changes in snow and ice cover or changes in the vegetation cover, and changes in vegetation cover or ocean surface properties that can transfer a seasonal forcing into an annual mean response (Braconnot, 2004). Analyses of the relationships between the orbital parameters of the Earth and the climate response rely on spectral proper- ties of the climate signals (Hays et al., 1976) versus spectral properties of incoming solar radiation (Berger, 1978), on the determination of phases between different climatic parameters and insolation in particular during transitions (Henderson and Slowey, 2000; Pépin et al., 2001; Shackleton, 2000); and modelling of the climate system response to selected orbital configurations (Gallée et al., 1992; Khodri et al., 2001).

In this section, we will focus on one aspect that is not usually described as essential in the driving of ice ages, which is the impact of changes in the obliquity of the Earth on the distribution of insolation, its imprint on the EPICA Dome C $\delta D$ record and finally its relevance when comparing different past, present and future orbital configurations and therefore climate evolutions.

\subsection{Latitudinal changes in incoming solar radiation}

We have displayed on Fig. 4 three components of today's incoming solar radiation: seasonal mean irradiance (total amount of solar energy received during an astronomical season, divided by the length of this season) for June-JulyAugust, annual mean and December-January-February, as a function of latitude. We have also displayed the deviations from this present-day latitudinal distribution of insolation, from the past $800 \mathrm{ka}$ to the next $200 \mathrm{ka}$, after calculations by Berger and Loutre $(1991,2002)$. 
When considering the seasonal redistribution of insolation, the clearest signal is associated with the precession of the equinoxes with periodicities of 19 to 23 kyears. The position of the seasons with respect to perihelion and aphelion induces seasonal redistributions of insolation with JJA or DJF magnitudes up to $60 \mathrm{~W} / \mathrm{m}^{2}$. The hemisphere where summer occurs at perihelion and winter at aphelion undergoes larger seasonal insolation contrasts than the other hemisphere. Therefore, precession has opposite effects on both hemispheres in terms of amplitude of insolation seasonal contrasts. Moreover, changes in the eccentricity of the orbit (up to $\sim 6 \%$ ) which take place with periodicities of $413 \mathrm{kyrs}$ and from 95 to $136 \mathrm{kyrs}$, modulate the impact of precession (Rial, 1999). Indeed, the impact of the position of the seasons on the Earth orbit is significantly smaller when the orbit is almost circular, as is the case today (current eccentricity of 0.017). This effect can be clearly seen in Fig. 4, with a modulation of amplitudes of the precession signals at $100 \mathrm{kyr}$ and $400 \mathrm{kyr}$ periodicities. In particular, the current situation, with a low eccentricity during the past $50 \mathrm{ka}$ and the future $100 \mathrm{ka}$ can be compared to the low eccentricity situation which took place from roughly 450 to $350 \mathrm{ka}$.

Finally, changes in the obliquity of the Earth also interact with changes in precession and eccentricity to modulate the seasonal contrasts (Loutre et al., 2004), with similar effects in both hemispheres. Obliquity varies between $\sim 22$ to $25^{\circ}$, and is today at the intermediate value of $23^{\circ} 27^{\prime}$. However, in contrast with eccentricity and precession, obliquity variations leave their signature in the annual mean insolation with opposite effects at low and high latitudes, the boundary being located at about $43^{\circ}$ north and south (Fig. 4). The magnitude of annual mean insolation variations remain limited compared to the seasonal variations, typically up to $10 \mathrm{~W} / \mathrm{m}^{2}$ (about $1 \%$ of annual mean insolation in the tropics and $5 \%$ of annual mean insolation in the high latitudes). Variations of obliquity result from nearby pseudo-periodicities at about $40 \mathrm{kyrs}$, therefore resulting in an apparent $41 \mathrm{kyr}$ periodicity and an amplitude modulation over 1.2 million years (Mélice et al., 2001; Liu, 1999; Pälike and Shackleton, 2001). This long term effect on the maximum and minimum obliquity levels can be distinguished in Fig. 3 (lower panel, annual mean insolation at $75^{\circ} \mathrm{S}$ ) and Fig. 4. During the past $200 \mathrm{ka}$, the maximum difference between obliquity maxima and minima is about $50 \%$ larger than during the period from 800 to $600 \mathrm{ka}$. When considering annual mean insolation at $75^{\circ} \mathrm{S}$, with an average value of $185.6 \mathrm{~W} / \mathrm{m}^{2}$, it can be shown that the amplitude between minima and maxima (occurring at a $41 \mathrm{kyr}$ pacing) ranges between $5 \mathrm{~W} / \mathrm{m}^{2}$ (at $680 \mathrm{ka}$ ) and $14 \mathrm{~W} / \mathrm{m}^{2}$ (at $230 \mathrm{ka}$ ). Therefore, the effect of the modulation of amplitude of obliquity induces relative variations of $2.7 \%$ to $7.5 \%$ of high latitude insolation maxima and minima.

It is often considered that summer insolation at $65^{\circ} \mathrm{N}$ is the key aspect of insolation changes for glacial-interglacial climate changes, due to the specific configuration of land masses and their role for the building of continental ice caps.
Here we stress the fact that insolation changes vary with the season and latitude, with out of phase effects in the two hemispheres if considering precession only, but symmetric bipolar forcings when considering obliquity effects (Loutre et al., 2004). Recently, Huybers (2006) also highlighted the role of obliquity in driving integrated summer insolation.

\subsection{Imprint of obliquity on ice core isotopic records}

\subsubsection{Obliquity signal in ice core deuterium excess records}

Our thoughts on the role of obliquity on polar climate change were initially triggered by observed variations of deuterium excess in the Antarctic Vostok ice core. Deuterium excess, $\mathrm{d}=\delta D-8 \delta^{18} \mathrm{O}$, is a second-order isotopic parameter (Dansgaard, 1964) that corrects the deuterium fluctuations from the first order equilibrium fractionation effects and therefore reflects changes in the kinetic fractionation, occurring either at the evaporation stage (therefore conditioned by surface characteristics such as sea surface temperature, relative humidity and wind speed) (Merlivat and Jouzel, 1979) or during snowflake formation (Jouzel and Merlivat, 1984).

Past fluctuations of deuterium excess measured on the Vostok ice core appeared to be strongly modulated by fluctuations of obliquity (Vimeux et al., 1999; Vimeux, 2001). It was proposed that relative humidity co-varied with surface temperature at the ocean surface (Kavanaugh and Cuffey, 2003; Vimeux et al., 2001). The interpretation was then the following: a small obliquity induces a decrease in annual mean insolation at high latitudes, and an increase of annual mean insolation at low latitudes. Cooler high latitudes, warmer tropics, and a more efficient moisture transport should have been combined to generate less evaporation at high latitudes (with a smaller deuterium excess), more evaporation in the tropics (with a larger deuterium excess), and a larger contribution of high-excess low-latitude moisture to polar precipitation. High deuterium excess values are systematically observed during glacial inceptions over the past climatic cycles, suggesting that the high obliquity levels of these periods were inducing an active hydrological cycle and provided the moisture required to build ice sheets in the northern hemisphere at the same time as the poles are getting colder. Such a mechanism is also supported by atmospheric transport changes simulated by coupled climate models (Khodri et al., 2001, 2003, 2005; Vettoretti and Peltier, 2004). The first Greenland record of deuterium excess measured on GRIP ice core suggested that the obliquity signature can be detected symmetrically on the atmospheric water cycle in both hemispheres (Masson-Delmotte et al., 2005).

Recent papers have also highlighted the potential effect of obliquity to control seasonal and annual mean latitudinal insolation gradients between low and high latitudes, atmospheric water cycle and therefore climate and ice sheet mass balance (Loutre et al., 2004). This suggestion also had 
echoes in the paleoceanographic community (Raymo and Nisancioglu, 2003).

\subsubsection{Obliquity and ice ages}

It was argued that eccentricity periodicity at $400 \mathrm{kyr}$ induced a frequency modulation of its $100 \mathrm{kyr}$ component and is responsible for the variable duration of ice ages, with in particular shorter ice ages around $400 \mathrm{kyrs}$ (Rial, 1999). In the EPICA Dome C deuterium record, a similar feature is observed, with the shortest duration of ice ages of about $80 \mathrm{kyrs}$ before and after MIS11 (Fig. 3), corresponding to a minimum eccentricity configuration. It can be also argued that, in periods of low eccentricity, seasonal contrasts induced by precession are weaker (Fig. 4, Fig. 6) and therefore changes in obliquity at $\sim 40 \mathrm{kyr}$ periodicities have larger impacts. This effect was also suggested by Rial and Anaclerio (2000) based on spectral analyses of Vostok climate records. Finally, recent papers have also highlighted the role of obliquity variations in non linear phase locking the average frequency of glacial cycles (Ashknenazy and Tziperman, 2004) or controlling deglaciation thresholds (Parrenin and Paillard, 2004; Huybers and Wunsch, 2005) and integrated summer insolation (Huybers, 2006) have demonstrated that the late Pleistocene terminations are not independent of obliquity, and that terminations occurred at every second or third period of high obliquity.

\subsubsection{Obliquity signal in EPICA Dome $\mathrm{C}$ deuterium record}

The power spectrum of EPICA Dome C deuterium record shows a marked obliquity component over the past $400 \mathrm{kyrs}$, as earlier seen in Vostok (Yiou et al., 2001), which vanishes over the earlier period (prior to $400 \mathrm{kyr} \mathrm{BP}$ ). The long term obliquity imprint on EPICA Dome $\mathrm{C}$ deuterium profile can be analysed either based on the $\sim 40 \mathrm{kyr}$ component of a Multi Taper Method spectral analysis (Fig. 3), or by performing evolutionary spectral analyses (not shown; Jouzel et al., $2006^{4}$ ). In both cases, it is clear that the $\sim 40 \mathrm{kyr}$ periodicity has an increasing weight on central East Antarctic temperature from past to present, with a marked transition at $\sim 400 \mathrm{ka}$. This result is further discussed in Jouzel et al. $(2006)^{4}$ in terms of intensity of warm periods.

Obliquity has a strong imprint on EPICA Dome C temperature record (as shown clearly by its $40 \mathrm{kyr}$ component), especially during the past $450 \mathrm{kyrs}$ (Fig. 3). We suggest that the increasing imprint of obliquity on the record is related to the long term amplitude modulation of obliquity variations. The mechanism relating Antarctic temperature and obliquity is expected to be linked to high latitude annual mean insolation and local feedbacks (sea-ice, water vapour), changes in latitudinal insolation gradients and dynamical transport feed-

\footnotetext{
${ }^{4}$ Jouzel, J., Masson-Delmotte, V., Cattani, O., et al.: Orbital and millenial Antarctic climate variability over the last 800000 years, Nature, in review, 2006.
}

backs (advection of heat and moisture to Antarctica). It must be noted that the strong relationship between Antarctic temperature and atmospheric $\mathrm{CO}_{2}$ concentrations (Petit et al., 1999; Siengenthaler et al., 2005) remains preserved during the early ice ages recorded at EPICA Dome C. It has been hypothesised that changes in the atmospheric greenhouse composition through variations of the carbon cycle controlled by processes in the high southern latitudes may also act as an amplifier for the imprint of obliquity on global climate, including the tropical Pacific where the local direct effect of obliquity is weak (Lea, 2004; Medina-Elizalde and Lea, 2005; Lawrence et al., 2006).

This strong increase of the obliquity component in Antarctic temperature over the past 800000 years is in sharp contrast with the longer term perspective offered by marine sediments. Indeed, paleoceanographic data (Liesicki and Raymo, 2005) show that the variance of the global ice volume is dominated by a $40 \mathrm{kyr}$ periodicity prior to 1 million years, and that a $100 \mathrm{kyr}$ periodicity appears on top of this $40 \mathrm{kyr}$ periodicity during the past 1 million years. During ice ages, continental ice caps are expected to be built at latitudes that are located between 50 and $65^{\circ} \mathrm{N}$, where the local impact of obliquity on annual mean insolation and temperature is expected to be less strong than at polar locations (see Sect. 3.3). Therefore, it is possible that effects of obliquity on high latitude temperatures would be more clearly marked in records of polar temperatures than in records of global sea-level. This analysis of the role of obliquity on Antarctic temperature builds on an understanding of a key role of precession and northern hemisphere summer insolation in controlling the timing of transitions and identified from their precise dating (e.g. Hays et al., 1976).

\subsection{Simulation of obliquity imprint on Antarctic tempera- tures}

In order to assess the relative impact of extreme orbital configurations, in the spirit of the pioneer work of (Gallimore and Kutzbach, 1995), an intermediate complexity climate model, ECBilt-CLIO (Goosse and Fichefet, 1999; Opsteegh et al., 1998) was used to perform a set of simulations under contrasted orbital configurations (Tuenter et al., 2005). The atmospheric component ECBilt2 is a global spectral quasigeostrophic model truncated at T21. There are 3 layers in the vertical. ECBilt has simple parameterisations for the diabatic heating due to radiative fluxes, the release of latent heat and the exchange of sensible heat with the surface. The model contains a full hydrological cycle which is closed over land by a bucket model for soil moisture. The ocean/sea-ice model is CLIO, a primitive equation, free-surface ocean general circulation model with a thermodynamic-dynamic seaice model. The horizontal resolution is $3^{\circ} \times 3^{\circ}$ and it has 20 unevenly spaced vertical levels. The ocean model has a relatively sophisticated parameterization of vertical mixing. The three-layer sea-ice model takes into account sensible and 


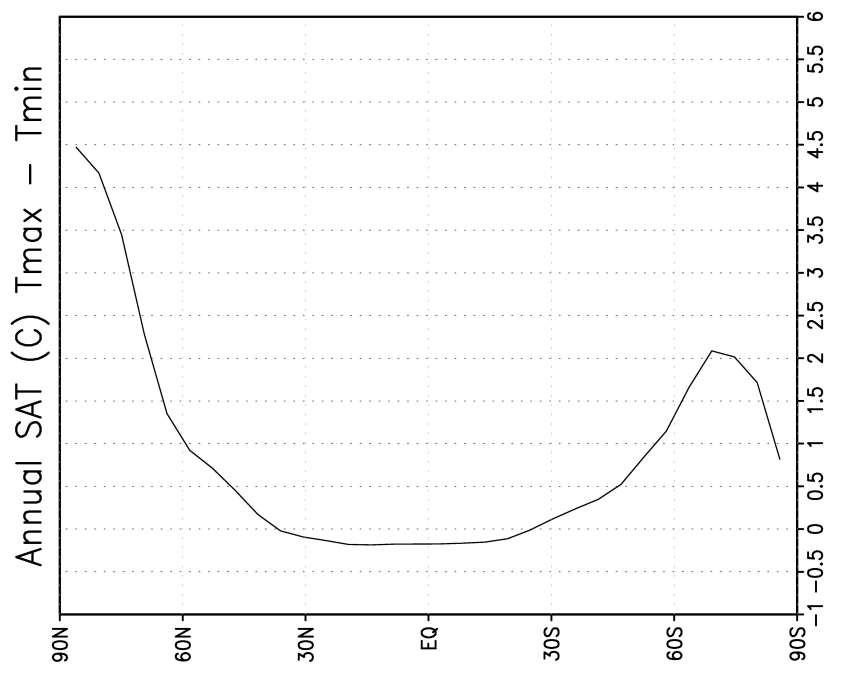

Fig. 5. Latitudinal temperature change simulated by the ECBILTCLIO model of intermediate complexity between maximum and minimum obliquity forcing.

latent heat storage in the snow-ice system. It simulates the changes of snow and ice thickness in response to surface and bottom heat fluxes; sea-ice is considered to behave as a viscous-plastic continuum. There is no local flux correction in ECBilt-CLIO. However, the model overestimates the precipitation over the Atlantic and Arctic oceans and underestimates the precipitation over the North Pacific (Opsteegh et al., 1998). Therefore the precipitation is artificially reduced by $10 \%$ over the Atlantic basin and $50 \%$ over the Arctic basin. The corresponding water is redistributed homogeneously over the North Pacific.

Two experiments simulations have been run with extreme values of obliquity $\left(22.08^{\circ}\right.$ and $\left.24.45^{\circ}\right)$, with a small nonzero eccentricity $(0.001)$ because a zero eccentricity caused numerical instabilities in the model. The initial state for all simulations is the present day state. The only forcing is the insolation change due to the orbital parameters, which were kept constant during the simulations. All other boundary conditions like ice sheets, vegetation and concentration of trace gases were kept to present day values. All experiments were run for $500 \mathrm{yrs}$. The mean response is defined as the average over the last 100 yrs.

Figure 5 shows the latitudinal temperature change induced by obliquity only maxima. As expected from the obliquity effect on insolation, tropical areas respond by a small cooling (within $0.3^{\circ} \mathrm{C}$ ), whereas high latitudes are simulated to react strongly to obliquity forcing, with warming amplitudes up to $2^{\circ} \mathrm{C}$ in Antarctica (and the austral ocean) and $4^{\circ} \mathrm{C}$ in the Arctic. Another model of intermediate complexity run under idealised orbital configurations (Kageyama et al., 2006 ${ }^{5}$ ) shows a similar latitudinal response to obliquity forcing (not

\footnotetext{
${ }^{5}$ Kageyama, M.: in preparation, 2006.
}

shown). These magnitudes correspond to about one forth of the full glacial-interglacial temperature amplitude.

This sensitivity study confirms that extreme configurations of obliquity alone, without including associated feedbacks such as land surface and carbon cycle changes, have the capability to significantly change polar temperatures. The potential of the sea-ice extent to act as a key climate amplifier has been highlighted from conceptual considerations (Gildor and Tziperman, 2000). The simulations conducted with ECBILTCLIO provide a quantitative confirmation on our arguments that changes in obliquity significantly impact high latitude temperatures.

\subsection{Comparison between MIS11 and the current inter- glacial}

Several authors have attempted to forecast what should be the natural orbitally-driven climate evolution over the next tens of thousand years. Such long-term forecasts cannot be made with three dimensional climate models coupled to ice sheet models yet, and rely on more conceptual models (Imbrie and Imbrie, 1980). These conceptual models take into account specific aspects of the insolation forcing, such as $65^{\circ} \mathrm{N}$ mid-June insolation, and include a crude representation of feedbacks within the climate system (albedo effect, time constant of ice sheet growth and decay and sometimes carbon cycle and atmospheric greenhouse gas content) in order to represent the non linear response of the climate system to the orbital forcing. As a result, such models allow the determination of thresholds in the incoming solar radiation that may induce the shift from different states of the climate system (typically from glacial to interglacial conditions, with the main climate parameter being the global ice volume) (Paillard, 1998). Such an approach seems supported by recent simulations conducted with a climate model of intermediate complexity (Calov and Ganopolski, 2005). Of course, a basic understanding of the orbital controls of past ice ages warrants a minimum realism in forecasts on future orbitallydriven future climate change. Considerations on the fate of anthropogenic $\mathrm{CO}_{2}$ in the atmosphere have shown that its long term decay and remaining radiative forcing may play a major role on the climate response to orbital forcing over the next tens of thousands of years (Archer and Ganopolski, 2005).

Several authors have worked on the comparison between the present and future orbital configuration and the orbital configurations that ended earlier interglacial periods. Due to the low eccentricity context occurring now and which will persist over the next tens of thousands of years, the precession fluctuations induce only limited changes in the northern hemisphere summer insolation (Fig. 2, Fig. 6). The horizontal dashed lines on Fig. 2 show for instance that the minimum of incoming northern hemisphere summer insolation that occurred at $\sim 115 \mathrm{ka}\left(\mathrm{JJA}\right.$ at $\left.75^{\circ} \mathrm{N}\right)$ and corresponded to the last glacial inception was $30 \mathrm{~W} / \mathrm{m}^{2}$ (or $\sim 7 \%$ ) below 

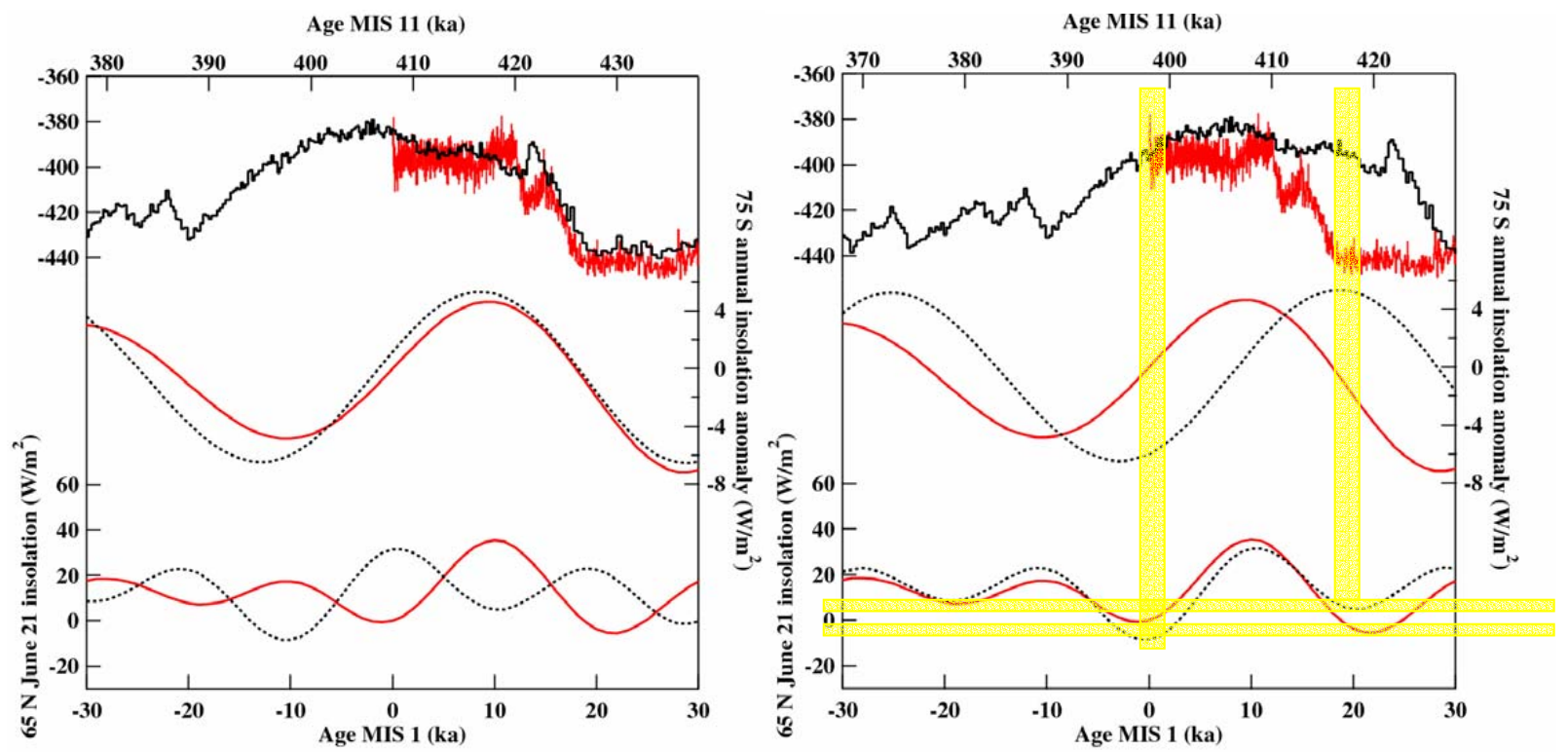

Fig. 6. Comparison of EPICA Dome C deuterium profile and orbital forcing for the past and future $30 \mathrm{kyrs}$ (red) and for a $60 \mathrm{kyr}$ time period encompassing stage 11 (black). Two components of the orbital forcing are displayed: the anomalies from present-day of annual mean insolation at $75^{\circ} \mathrm{S}$ (basically corresponding to the obliquity signal) and the anomalies of mid-June insolation at $65^{\circ} \mathrm{N}$. Different approaches have been developed to compare the transition from MIS 12 to MIS 11 and from MIS 2 to MIS 1 . If the terminations are supposed to start simultaneously, this corresponds to a synchronisation of the obliquity fluctuations (left). This approach was followed by EPICA-community-members (2004). If the precession effect on $65^{\circ} \mathrm{N}$ mid-June insolation is synchronised, this places the terminations and the obliquity variations out of phase (right). This approach was initially suggested by Berger and Loutre (2002) and further followed by Ruddiman (2003). It has been suggested that thresholds on summer insolation are involved in the onset of ice ages. During the warm Antarctic episode corresponding to MIS 11, a first minimum of summer insolation is observed at $\sim 420$ ka. This minimum does not produce a glacial inception (horizontal dashed line labelled 1). The end of MIS 11 at Dome C corresponds to a second deeper minimum of summer insolation, at about $395 \mathrm{ka}$ (horizontal dashed line labelled 2). It must be noted that the current minimum of mid-June insolation at $65^{\circ} \mathrm{N}$ lies between the first level (which did not cause the glacial inception in the beginning of MIS 11) and the second level (which corresponded to the end of MIS 11).

today's minimum. It is therefore difficult to extrapolate the thresholds that induced glaciations at the end of the previous interglacial to the current and future situation.

Berger and Loutre (2002) suggested that an orbital analogy could be made between the future orbital configuration and the one that was observed to take place during MIS11, 405 to $340 \mathrm{ka}$. This analogy results from a similar modulation of precession effect by a low eccentricity (the distance between this period and today corresponds to the $413 \mathrm{kyr}$ periodicity in eccentricity). The comparison was further strengthened by simulations conducted with a two dimensional climate model (Loutre and Berger, 2003; Berger et al., 2003). Such simulations suggested that the orbital forcing would not be triggering a glacial inception until $50 \mathrm{ka}$ after present. However, by comparing the evolution of Vostok atmospheric $\mathrm{CH}_{4}$ concentrations during the early Holocene and the 3 previous interglacial periods, assumed to be related to the precession forcing (Ruddiman and Raymo, 2003), Ruddiman (2003) suggested that we have passed the northern hemisphere summer insolation threshold required to start a glaciation several mil- lennia ago. The use of the atmospheric $\mathrm{CH}_{4}$ fluctuations to detect glacial inception remains difficult, partly because (i) the magnitude of the precession-driven fluctuations remains limited during interglacial periods (Schmidt et al., 2004) and that (ii) $\mathrm{CH}_{4}$ fluctuations during MIS11 exhibits a minimum such as the one encountered during the Holocene, without being associated with a glacial inception(Spahni et al., 2005).

Interestingly, the EPICA Dome $\mathrm{C}$ record can be used to compare the Antarctic temperature evolution during the current interglacial period and this MIS11 interglacial period, which was also archived in Vostok ice (Raynaud et al., 2005). In the EPICA community paper (EPICA-communitymembers, 2004), the records of MIS11 and MIS1 were synchronised by aligning the terminations, so that the presentday corresponds to a warming trend prior to MIS11 peak warmth ( $\sim 407 \mathrm{ka})$ (Fig. 6a). It was then argued that the current interglacial period could last as long as the remaining $16 \mathrm{kyr}$ duration of MIS11, assumed to end at $\sim 395 \mathrm{ka}$, and citing the orbital analogy proposed initially by Berger and Loutre (2002). 
This synchronisation was heavily questioned by Ruddiman (2005), who pointed out that the (EPICA-communitymembers, 2004) synchronisation was incorrect in terms of orbital analogy. Indeed, if one was to align the pure precession signal, then the best orbital analogy is found by aligning the present-day situation with the end of MIS11, at $\sim 397$ ka (Fig. 6b), following the initial orbital analogy given by Berger and Loutre (2002). The level of the current minimum of $\mathrm{NH} 65^{\circ} \mathrm{N}$ mid-June insolation lies exactly between (i) a small minimum occurring at $420 \mathrm{ka}$, in the first warming phase of MIS11 at EPICA Dome C, which was clearly not associated with the onset of an ice age, and (ii) a more marked minimum occurring at $399 \mathrm{ka}$, which corresponds to the rapid cooling marking at EPICA Dome C the end of MIS11.

To our opinion, the pure alignment of the precession signal between MIS11 and MIS1 does not support the argument that the current insolation minimum at $65^{\circ} \mathrm{N}$ in summer is the threshold to induce a glacial inception. The long duration of MIS11 results probably from a "skipped" precession cycle, in the context of a low eccentricity, and a similar situation may as well occur in the next tens of thousand years because no $65^{\circ} \mathrm{N}$ summer insolation minima as low as those that induced the previous ice ages is expected to occur, nor the occurrence of a small minimum of this parameter together with a minimum of obliquity (Fig. 6).

The temperature trend recorded in EPICA Dome $\mathrm{C}$ ice core during the Holocene can also be compared with earlier interglacial periods (Fig. 3, Fig. 6). There is no clear decreasing $\delta D$ trend at Dome $\mathrm{C}$ over the past millennia (MassonDelmotte et al., 2004); this is in contrast with small cooling trends observed at other Antarctic deep ice core sites (Masson et al., 2000). The late Holocene climate trends (or lack of trends) recorded at various Antarctic places may be significantly influenced by a few tens of meter changes in the relative local elevation because of the ice sheet volume and dynamics (Masson et al., 2000). Ice sheet modelling results suggest that the elevation has been slightly increasing at deep ice core sites such as Dome $\mathrm{C}$ over the past millenia (Lhomme, 2004). The lack of cooling trend cannot be accounted for by elevation changes. It is therefore difficult to argue, based on EPICA Dome $\mathrm{C}$ deuterium record for the Holocene, that the current interglacial is reaching its end, because central Antarctic temperatures do not appear to be cooling. The Holocene trend, in this respect, is extremely different from the deuterium fluctuations over MIS 5, 7 and 9 (marked by an early interglacial peak warmth immediately followed by a cooling trend without a stable "plateau"). It shows more similarity with the stable or slowly rising deuterium levels during the beginning of MIS11, 13, 15 or 17.

Finally, we argue that the alignment of MIS11 and MIS1 performed in (EPICA-community-members, 2004) is not only an alignment of the terminations, but also an alignment of the obliquity fluctuations during the two periods (Fig. 6a). In the previous subsection, we have reviewed both the EPICA deuterium spectral evidence, some modelling re- sults and the literature which suggest that obliquity fluctuations have a marked signature on both the termination and glacial inceptions. We propose that, when the eccentricity is small and therefore the precession minima and maxima are weak, the role of obliquity cannot be neglected in triggering deglaciations and glaciations. In this respect, it is important to see that there is no perfect orbital analog for the presentday and future orbital context (Berger et al., 1998). Today, the obliquity is at an intermediate value, whereas the end of MIS11 occurred when both the summer insolation and the obliquity were minimal. If obliquity is playing a larger than invoked role on ice ages, then it cannot be expected that an ice age would be to occur over the next $50 \mathrm{ka}$, until minima of obliquity and $\mathrm{NH}$ summer insolation coincide.

\section{Magnitude and pacing of past and future temperature changes}

Ice core based climate records are not only relevant for future climate changes at the orbital time scales. The polar temperature reconstructions can be used to test the capabilities of climate models, used to assess climate risks over the next centuries, to capture the full magnitude of past climate changes.

The increase of atmospheric $\mathrm{CO}_{2}$ concentration caused by human activities is already considered to be a significant climate forcing factor (IPCC, 2001), and expected to persist over the next thousands to tens of thousands of years (Archer and Ganopolski, 2005). In this section, we compare the magnitude and pacing of $\mathrm{CO}_{2}$ induced climate change simulated at polar locations by coupled climate models run under a forcing of increasing atmospheric $\mathrm{CO}_{2}$ concentrations at a rate of $1 \%$ per year (see Sect. 1.2), to the past reconstructed polar temperature changes based on ice core data (see Sect. 1.3) and to simulations forced by Last Glacial Maximum boundary conditions.

These comparisons allow an assessment of the capability of climate models to capture glacial-interglacial polar temperature changes, of the global relevance of deep ice core temperature reconstructions, and a comparison of the anthropogenic climate risk with the past natural climate evolution at deep ice core sites: can the $\mathrm{CO}_{2}$-induced polar warming be considered as an "abrupt" climate change?

\subsection{Model intercomparison: LGM, $2 \times \mathrm{CO}_{2}$ and $4 \times \mathrm{CO}_{2}$ at polar locations}

With standardized simulations, it is possible to analyse the mean model response together with the uncertainty from model to model. The upper panels of Fig. 9 display the deviations between Last Glacial Maximum and pre-industrial, and pre-industrial to $2 \times$ and $4 \times \mathrm{CO}_{2}$ simulations (MassonDelmotte et al., 2006) and the bottom panels the standard deviation between the various climate models. The global 

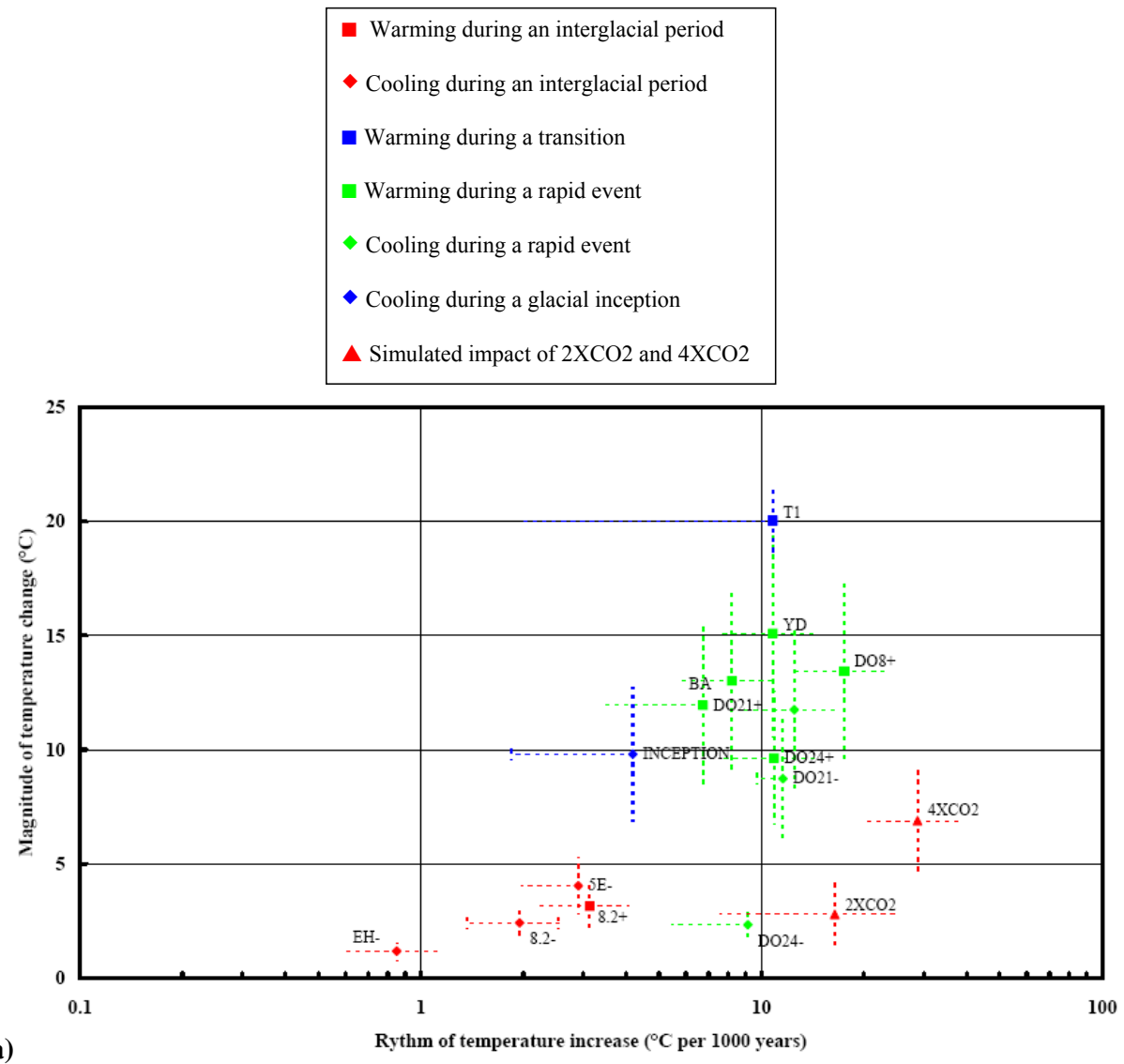

(a)

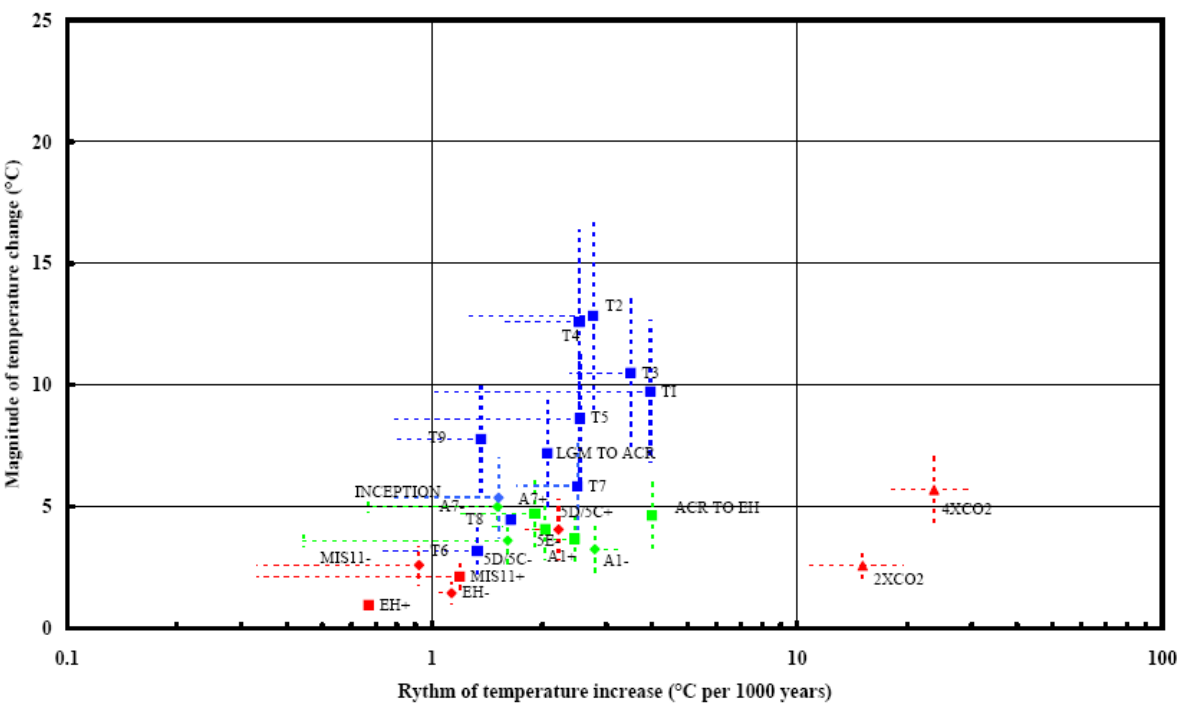

Fig. 7. Overview of the magnitude and rapidity of temperature changes in Greenland (a) and Antarctica (b) from ice core estimates and sensitivity studies conducted with coupled climate models $\left(2 \times \mathrm{CO}_{2}\right.$ and $\left.4 \times \mathrm{CO}_{2}\right)$. See text for details. $\mathrm{EH}( \pm)$ stands for warming/cooling before and after the Early Holocene temperature optimum (Masson-Delmotte et al., 2004); A1 $( \pm$ ) for the warming/cooling before and after the A1 temperature maximum (Blunier and Brook, 2001); $\mathrm{A} 7( \pm)$ for the warming/cooling before and after the A7 temperature maximum (Blunier and Brook, 2001); 5d/5c( \pm ) for the warming/cooling before and after the first rapid event in Antarctica (Caillon et al., 2001); LGM for the Last Glacial Maximum; ACR for the Antarctic Cold Reversal; T1 to T9 for the terminations. These events are also located on the deuterium profile of EPICA Dome C on Fig. 3. 


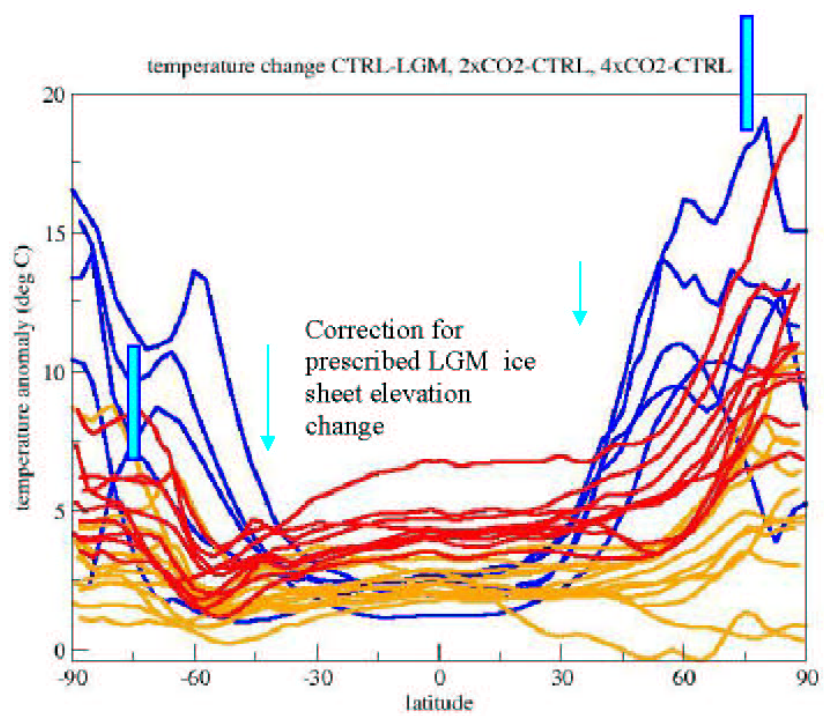

Fig. 8. Latitudinal surface air temperature change simulated by coupled climate models for the change between Last Glacial Maximum and pre-industrial (PMIP2 intercomparison) (blue lines) and for the change between $2 \times \mathrm{CO}_{2}$ (orange lines) and $4 \times \mathrm{CO}_{2}$ (red lines) and pre-industrial (CMIP intercomparison performed for IPCC). The simulations are described in Masson-Delmotte et al. (2006). Vertical blue rectangles at $75^{\circ} \mathrm{N}$ and $75^{\circ} \mathrm{S}$ correspond to estimates of temperature ranges based on ice cores. The vertical arrow corresponds to the correction for estimating polar temperature changes at ice core sites. LGM model simulations were run with the ICE5G topography (Peltier, 2004) which suggests a 350 to 400 m elevation increase in central Antarctica and central Greenland. With a vertical lapse rate of $10^{\circ} \mathrm{C}$ per $1000 \mathrm{~m}$, such a higher elevation is expected to induce a local cooling of 3.5 to $4^{\circ} \mathrm{C}$. The ice core air content signals do not suggest such large elevation changes (Krinner and Genthon, 1999).

temperature change is simulated to be $4.2 \pm 0.9^{\circ} \mathrm{C}$ from LGM to pre-industrial, $2.1 \pm 0.4^{\circ} \mathrm{C}$ for pre-industrial to $2 \times \mathrm{CO}_{2}$ and $4.7 \pm 1^{\circ} \mathrm{C}$ to $4 \times \mathrm{CO}_{2}$. At the global scale, the magnitude of a quadrupling of $\mathrm{CO}_{2}$ levels is therefore comparable in magnitude to the warming since the LGM.

However, these warmings are not homogeneous over the Earth's surface. Figure 8 shows that $2 \times$ and $4 \times \mathrm{CO}_{2}$ simulations are associated with warmer temperatures in the tropics compared to the simulated change from LGM to presentday. The explanations for this differential latitudinal response have not been fully analysed yet. Obviously, the forcings themselves also differ in their spatial properties, with a strong north/south asymmetry induced by prescribed northern hemisphere ice sheets for the LGM.

We propose that two main features may be involved in these latitudinal temperature gradients: (i) non linear water vapour and cloud feedbacks that would depend on the mean climate state (and therefore would not be symmetric for a colder period such as the LGM versus warmer states such as resulting from $\mathrm{CO}_{2}$ increases); (ii) changes in the latitudinal transport of heat by the ocean and atmosphere simulations. Indeed, coupled model simulations show a weakening of the thermohaline ocean circulation in $\mathrm{CO}_{2}$ increase simulations, possibly associated with a decreased export of heat from the tropics to the high latitudes and therefore an increase of tropical temperatures (Houghton, 2001).

In all the climate change experiments described here, a strong polar amplification is also simulated, north or south of $40^{\circ}$ for the change since the LGM, and north or south of $60^{\circ}$ for the $\mathrm{CO}_{2}$ induced changes. Polar amplification processes are thought to be associated with changes in the surface albedo feedbacks (including land ice and sea ice effects), the cloud/water vapour atmospheric feedbacks (Holland and Bitz, 2003; Masson-Delmotte et al., 2006; Solomon, 2006) and prescribed changes in ice sheet topography (elevation effect on temperatures at the surface of the ice caps) (MassonDelmotte et al., 2006).

The average temperature change in the central Antarctic plateau (above $2500 \mathrm{~m}$ ) is simulated to be $8.5 \pm 3.8^{\circ} \mathrm{C}$ from LGM to pre-industrial (on average twice the global change), and respectively $2.6 \pm 0.7^{\circ} \mathrm{C}$ and $5.7 \pm 1.4^{\circ} \mathrm{C}$ in response to a doubling or quadrupling of atmospheric $\mathrm{CO}_{2}$ concentrations (see also Figs. 8 and 9). The dispersion from model to model is much larger for the LGM, possibly due to differences in models simulations of ocean circulation and sea-ice changes, and in this case reaches about half of the full amplitude. When compared to ice core based estimates, it seems that climate models do capture the right amplitude (about $9 \pm 2{ }^{\circ} \mathrm{C}$ at Dome $\mathrm{C}$ for the LGM) (blue rectangles on Fig. 8) (Stenni et al., 2001). However, the prescribed ICE-5G ice sheet topography change $(-400 \mathrm{~m}$ for central East Antarctica from the LGM to present-day) accounts for half of the simulated amplitude (taking into account a vertical lapse rate of $10^{\circ} \mathrm{C}$ per $1000 \mathrm{~m}$ ) and is in conflict with opposite trends in elevation derived from ice core air content information (Martinerie et al., 1994) and from three dimensional ice sheet modelling (Ritz et al., 2001). Without changes in ice sheet elevation, climate models would significantly underestimate LGM temperature changes at Antarctic ice core locations, possibly because forcings such as changes in the dust content of the atmosphere and land cover changes are not taken into account. Recent modelling studies have indeed shown that changes in vegetation cover at the LGM enhances northern hemisphere glacial cooling (Crucifix and Hewitt, 2005). Changes in atmospheric dust load is considered to have a major effect on tropical radiative forcing (Claquin et al, 2003); changes in dust deposition on snow are also suggested to have important effects on ice sheet growth in the northern hemisphere (Krinner et al., 2006). This comparison suggests a need for further sensitivity tests conducted with coupled climate models and the full range of changing LGM boundary conditions including dust content of the atmosphere and vegetation cover, with a detailed comparison to temperature reconstructions at various latitudes. 

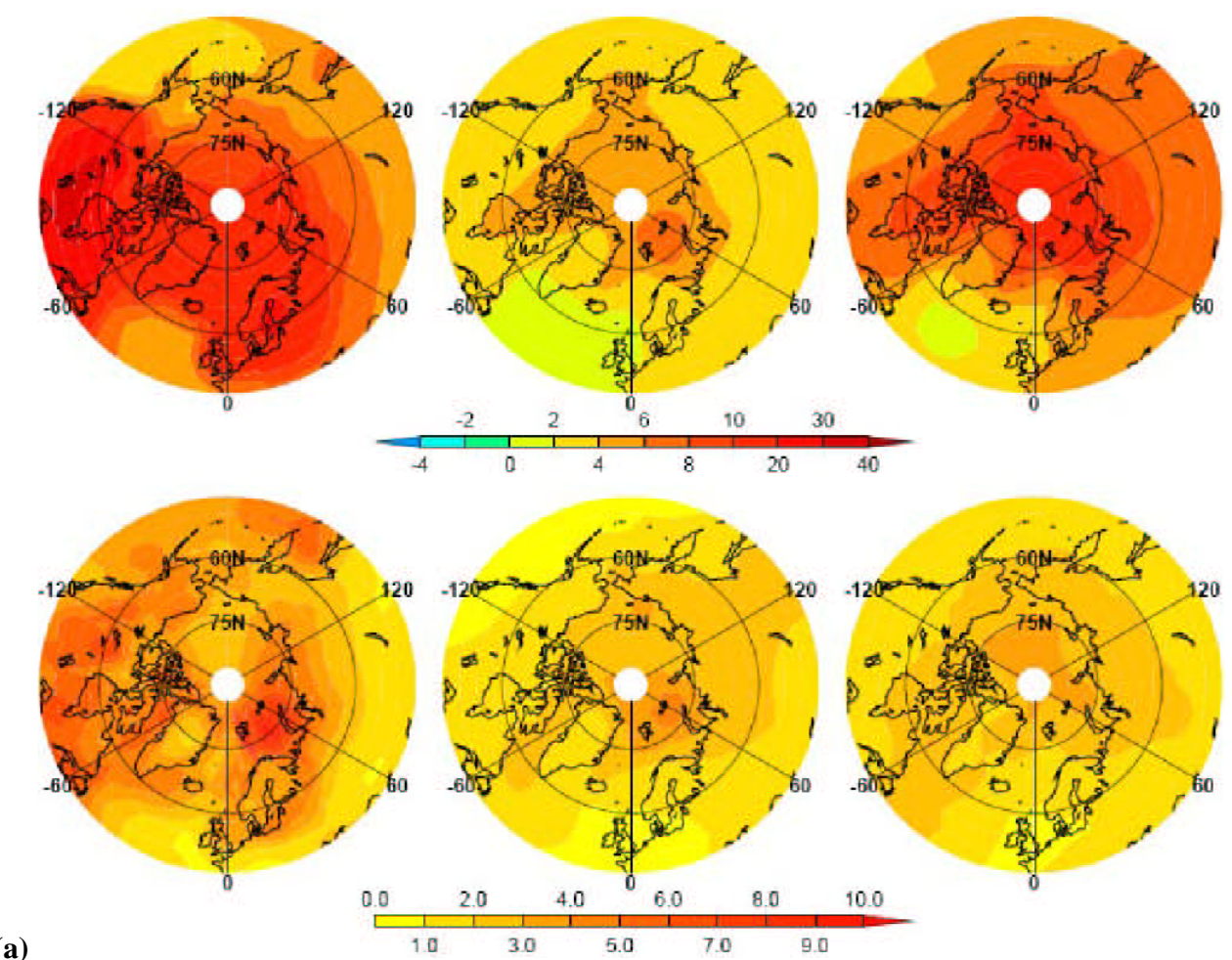

(a)
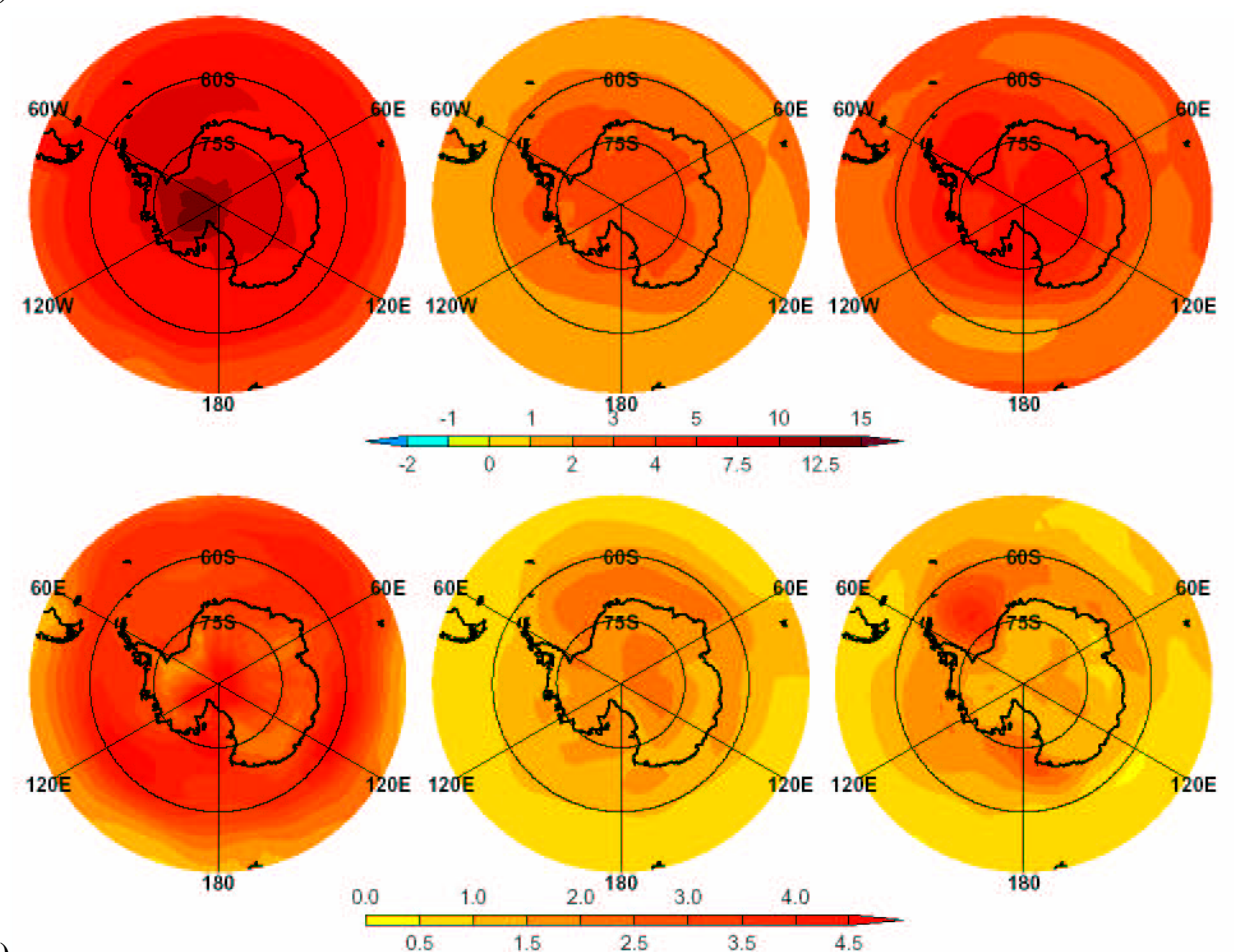

Fig. 9. Greenland (a) and Antarctic (b) surface air temperature change simulated by coupled climate models for the change between Last Glacial Maximum and pre-industrial (PMIP2 intercomparison) (left) and for the change between $2 \times \mathrm{CO}_{2}$ (center) and $4 \times \mathrm{CO}_{2}$ (right) and pre-industrial (CMIP intercomparison performed for IPCC). Top panels: average of model results. Bottom panels: inter-model standard deviation. The simulations are described in Masson-Delmotte et al. (2006). 
The average temperature change in central Greenland (above $1300 \mathrm{~m}$ ) is simulated to be $10.9 \pm 3.5^{\circ} \mathrm{C}$ from LGM to pre-industrial (on average twice the global change), and respectively $2.9 \pm 1.5^{\circ} \mathrm{C}$ and $6.9 \pm 2.0^{\circ} \mathrm{C}$ in response to a doubling or quadrupling of atmospheric $\mathrm{CO} 2$ concentrations (see also Fig. 9). Again, climate models systematically underestimate the magnitude of LGM to present-day changes, estimated to be larger than $20^{\circ} \mathrm{C}$ from borehole thermometry (Dahl-Jensen et al., 1998) (blue rectangle on Fig. 8). The model underestimation of LGM temperature change may be caused not including changes in the atmospheric aerosol load and land surface changes, which could change the northern hemisphere atmospheric circulation and enhance the glacial cooling over Greenland.

In all the simulations, the dispersion from model to model appears to be particularly large in the sea-ice areas, suggesting that the simulated sea-ice response differs strongly from model to model.

4.2 Comparison of magnitude and pacing at deep ice core sites

In order to compare both the magnitude and pacing of the different types of climate changes recorded in GRIP, NorthGRIP and EPICA Dome $\mathrm{C}$ ice cores, we have used the following method. For each climate event labelled on Fig. 7, we have worked on temperature reconstructions (see Sect. 1) resampled at a 100 year time step. We have then estimated the magnitude of the temperature change during the event (from minimum to maximum values), the duration of the event, the mean pacing of temperature change (by dividing the magnitude by the duration) and the most rapid pacing during the event. This maximum pacing was obtained by calculating the successive temperature-time slope over 1000 years centred onto each time step of 100 years. In Fig. 7, both cooling and warming events are displayed as positive values, but with different symbols. For comparison, the $2 \times$ and $4 \times \mathrm{CO}_{2}$ simulations are analysed at the end of a $\sim 170$ and $\sim 240$ year time period respectively, and we have only displayed their mean rhythm. Uncertainties on temperature magnitude are assumed to be of $30 \%$, apart for the glacial-interglacial amplitude in Greenland which is more precisely constrainted by borehole temperature profiles. Uncertainties on the pacing have been obtained by considering the uncertainty on the temperature estimate and the difference between the mean and most rapid duration of the events. We have chosen to present a pacing calculated on a 1000 year basis because (i) this gives orders of magnitude more easy to handle than on a 100 year basis; (ii) this enables to make a reasonable use of the Antarctic temperature reconstruction (on a 100 year time step). We are aware that it requires an extrapolation of more rapid (subcentennial) temperature changes as reconstructed from Greenland data and from climate simulations.

For Greenland, we have selected the following climate changes: the early Holocene temperature optimum, the
8.2 cooling event (Alley and Agustsdottir, 2005; MassonDelmotte et al., 2005), the full termination I and the subsections corresponding to the warming from LGM to Bölling/Alleröd, and from the Younger Dryas to the Early Holocene; the DO events 8, 21 and 24, corresponding to rapid events at different moments of the last ice age; the cooling from the maximum MIS5e warmth to the presentday temperature. The largest magnitude of past temperature changes in Greenland is up to $20^{\circ} \mathrm{C}$ on the glacial interglacial time scale, much larger than the $4 \times \mathrm{CO}_{2}$ induced changes. However, the most rapid temperature increases are observed to occur during DO events such as the DO8 or DO24. Such rapid temperature changes have magnitudes larger than $9^{\circ} \mathrm{C}$ and a pacing that can be as high as $17.5^{\circ} \mathrm{C}$ per 1000 years. In Greenland, temperature changes taking place during warm periods are reconstructed to be much slower than those taking place during cold periods, with the fastest "interglacial" change occurring during the glacial inception, with a maximum pacing of $4^{\circ} \mathrm{C}$ per 1000 years. The warming expected to be induced by a constant $1 \% \mathrm{CO}_{2}$ increase until reaching 2 times the pre-industrial $\mathrm{CO}_{2}$ level is at least expected to be as fast as the fastest past temperature changes. Furthermore, the simulated warming under $\mathrm{CO}_{2}$ increase does not take possible amplifying changes in ice sheet elevation into account, which would result in a faster and larger warming.

The situation is more contrasted in Antarctica. We have compared the magnitude and speed of all terminations, separating termination I into the first and second warming phases separated by the Antarctic Cold Reversal. We have also represented the Antarctic counterparts of the same DO events discussed earlier for Greenland (A1, A7 and 5d/5c events), as well as the trends before and after the Early Holocene and MIS11 maxima, and during the last glacial inception (from 5e to 5d). Based on the EPICA Dome C EDC2 age scale and deuterium profile, the fastest past change is observed in the transition from the Antarctic Cold Reversal to the Early Holocene, with a maximum pacing of $4^{\circ} \mathrm{C}$ per 1000 years. During the warm periods, past changes are reconstructed to occur with a smaller pacing, typically $1.5^{\circ} \mathrm{C}$ per 1000 years in the warming phase to MIS11 or less than $1{ }^{\circ} \mathrm{C}$ per 1000 years in the Holocene. Although the magnitude of $\mathrm{CO}_{2}$ induced projected local warming is comparable to the magnitude of past natural changes (such as the peak warmth of MIS5e or MIS11), the pacing corresponding to the $1 \%$ per year $\mathrm{CO} 2$ increase is reaching $20^{\circ} \mathrm{C}$ per 1000 years in Antarctica, one order of magnitude larger than any of the changes recorded in EPICA Dome $\mathrm{C}$ deuterium-based temperature reconstruction.

\section{Conclusions and perspectives}

We have briefly reviewed the methods used to extract quantitative information on past temperature changes from deep ice cores and the magnitude and pacing of past temperature 
changes. These past temperature reconstructions have been shown to be relevant for future climate change.

First, the understanding of the mechanisms relating orbital parameters of the Earth and glacial inceptions is important for predicting the end of the current interglacial period. Most studies have suggested that thresholds in northern hemisphere summer insolation are critical for inducing such major transitions. We suggest, based on the analysis of the EPICA Dome $\mathrm{C}$ deuterium profile and simulations conducted with a climate model of intermediate complexity, that changes in obliquity play a significant role on the evolution of polar temperatures. In periods of low eccentricity such as during MIS11 and during the current interglacial period, limited fluctuations of northern hemisphere summer insolation are observed and obliquity effects should be proportionally larger. The comparison of polar temperature evolution during MIS11 and the Holocene published by (EPICA-communitymembers, 2004) corresponded to a synchronisation of their obliquity fluctuations. Finally, it must be noted that no past analogue can be found for the current and future orbital context, and that there is no conjunction of a minimum of obliquity and a minimum of northern hemisphere summer insolation (the orbital context required to produce a glacial inception in a context of low eccentricity) to occur during the next tens of thousand years. This analysis should be extended by taking into account the obliquity imprint on climate feedbacks such as the atmospheric dust and greenhouse gas content, which are being measured on the EPICA Dome $\mathrm{C}$ ice core (Siengenthaler et al., 2005; Spahni et al., 2005), and will benefit from improved ice core dating methods. Finally, the suggestion that the long term amplitude modulation of the obliquity could be responsible for lukewarm interglacials prior to MIS 11 could be tested by climate models.

Second, the glacial-interglacial temperature magnitude estimated from deep ice core locations can be used to test the capability of climate models to capture the observed intensity of polar temperature changes. In response to prescribed LGM ice sheet and sea level changes, and greenhouse composition changes, climate models systematically underestimate the magnitude of temperature change when compared to ice core based estimates. The model-data comparison is limited due to the fact that (i) climate models do not include all the climate feedbacks such as changes in atmospheric dust content, or changes in land surface vegetation, and (ii) there may be inconsistencies in the ice sheet topography used to force the models and the ice core indications. For the latter point, a way forward is the consistent modelling of the coupled climate/ice sheet transient responses. The effect of changes in ice sheet topography could also be tested with climate models. It is interesting to observe that, in the world of climate models, the magnitude of the simulated change in Antarctic temperature is related to the magnitude of global temperature change (both for LGM and future climate scenarios).
Although the forcings are different, the magnitudes and pacing of $\mathrm{CO}_{2}$-induced temperature changes can be compared to the natural fluctuations of polar temperatures derived from ice cores. In Greenland and Antarctica, peak warmth has been estimated to reach temperatures $5^{\circ} \mathrm{C}$ above present-day levels (at different periods of the 5e interglacial period). These estimates would benefit from analyses of the temperature-isotope relationships in MIS5e climate simulations conducted with "isotopic" general circulation models. We observe that the simulated magnitude of $\mathrm{CO}_{2}$-induced temperature change is comparable to the largest temperature changes undergone at polar locations (such as the glacialinterglacial amplitude or the change from today to the peak warmth of stage $5 \mathrm{e}$ ). The pacing of the polar temperature changes induced by a $1 \%$ per year $\mathrm{CO}_{2}$ increase is comparable or faster than the most abrupt temperature changes recorded in Greenland, whereas it is several times faster than any temperature change detected in central Antarctic ice cores and must therefore be considered as an abrupt climate change.

Acknowledgements. We thank the organizing committee of the PAGES Open Science Meeting in Beijing, August 2006. This work has been funded by the European Commission (contracts EPICA-MIS and MOTIF) and the French Agence Nationale de la Recherche (PICC project). We acknowledge the modelling groups for providing their data for analysis, the CMIP (Climate Model Intercomparison Project) and PMIP (Paleoclimate Modelling Intercomparison Project) for collecting and archiving the model data. We thank the NorthGRIP and EPICA project participants and S. Falourd, O. Cattani, and B. Minster for the processing and analyses of ice core samples at LSCE.

Edited by: J. Brigham-Grette

\section{References}

Alley, R. B. and Agustsdottir, A. M.: The $8 \mathrm{k}$ event: cause and consequences of a major Holocene abrupt climate change, Quaternary Sci. Rev., 24, 1123-1149, 2005.

Alley, R. B., Clark, P. U., Huybrechts, P., and Jouqhin, I.: Ice sheet and sea-level changes, Science in China, 310, 456-460, 2005.

Archer, A. and Ganopolski, A.: A movable trigger: fossil fuel $\mathrm{CO} 2$ and the onset of the next glaciation, Geochem. Geophys. Geosyst., 6, Q05003, doi:10.1029/2004GC000891, 2005.

Ashknenazy, J. and Tziperman, E.: Are the $41 \mathrm{kyr}$ glacial oscillations a linear response to Milankovitch forcing?, Quarternary Sci. Rev., 23, 1879-1890, 2004.

Bender, M., Labeyrie, L. D., Raynaud, D., and Lorius, C.: Isotopic composition of atmospheric $\mathrm{O}_{2}$ in ice linked with deglaciation and global primary productivity, Nature, 318, 349-352, 1985.

Berger, A.: Long-term variation of daily insolation and Quaternary climatic changes, J. Atmos. Sci., 35, 2362-2367, 1978.

Berger, A. and Loutre, M. F.: Insolation values for the climate of the last 10 million years, Quaternary Sci. Rev., 10, 297-317, 1991.

Berger, A. and Loutre, M. F.: An Exceptionally Long Interglacial Ahead?, Science, 297, 1287-1288, 2002. 
Berger, A., Loutre, M. F., and Crucifix, M.: The Earth's climate in the next hundred thousand years (100 kyr), Surveys in Geophysics, 24, 117-138, 2003.

Berger, A., Loutre, M. F., and Mélice, J. L.: Instability of the astronomical periods from 1.5 Myr BP to $0.5 \mathrm{Myr}$ AP, Paleoclimates, 2, 239-280, 1998.

Bintanja, R., Wal, R. v. d., and Oerlemans, J.: Modelled atmospheric temperatures and global sea levels over the past million years, Nature, 437, 125-128, 2005.

Blunier, T. and Brook, E.: Timing of millenial-scale climate change in Antarctica and Greenland during the last glacial period, Science, 291, 109-112, 2001.

Braconnot, P.: Modeling the last glacial maximum and midholocene, Comptes Rendus Geoscience, 336, 711-719, 2004.

Caillon, N., Severinghaus, J. P., Barnola, J.-M., Chappellaz, J., Jouzel, J., and Parrenin, F.: Estimation of temperature change and of gas age - ice age difference, $108 \mathrm{Kyr}$ BP, at Vostok, Antarctica, J. Geophys. Res., 106, 31 893-31 901, 2001.

Caillon, N., Severinghaus, J. P., Barnola, J. M., Chappellaz, J. C., Jouzel, J., and Parrenin, F.: Estimation of temperature change and of gas age - ice age difference, $108 \mathrm{kyr}$ BP, at Vostok, Antarctica, J. Geophys. Res., 106, 31 893-31 901, 2001.

Calov, R. and Ganopolski, A.: Multistability and hysteresis in the climate-cryosphere system under orbital forcing, Geophys. Res. Lett., 32, L21717, doi:10.1029/2005GL024518, 2005.

Chiang, J. C. H. and Bitz, C. M.: Influence of high latitude ice cover on the marine Intertropical Convergence Zone, Clim. Dyn., 25, 477-496, 2005.

Ciais, P. and Jouzel, J.: Deuterium and Oxygen 18 in precipitation: an Isotopic Model including Mixed Cloud Processes, J. Geophys. Res., 99, 16 793-16 803, 1994.

Claussen, M., Mysak, L. A., Weaver, A. J., Crucifix, M., Fichefet, T., Loutre, M. F., Weber, S. L., Alcamo, J., Alexeev, V. A., Berger, A., Calov, R., Ganopolski, A., Goosse, H., Lohmann, G., Lunkeit, F., Mokhov, I. I., Petoukhov, V., Stone, P., and Wang, Z.: Earth system models of intermediate complexity: closing the gap in the spectrum of climate system models, Clim. Dyn., 18, 579-586, 2002.

Cuffey, K. M., Alley, R. B., Grootes, P. M., and Anandakrishnan, S.: Towards using borehole temperatures to calibrate an isotopic paleothermometer in central Greenland, Global Planet. Change, 6, 264-268, 1992.

Cuffey, K. M. and Clow, G. D.: Temperature, accumulation, and ice sheet elevation in central Greenland through the last deglacial transition, J. Geophys. Res., 102, 26383-26 396, 1997.

Cuffey, K. M. and Marshall, S. J.: Substantial contribution to sealevel rise during the last interglacial from the Greenland ice sheet, Nature, 404, 591-594, 2000.

Cuffey, K. M. and Vimeux, F.: Covariation of carbon dioxyde and temperature from the Vostok ice core after deuterium-excess correction, Nature, 421, 523-527, 2001.

Dahl-Jensen, D. and Johnsen, S. J.: Paleotemperatures still exist in the Greenland ice sheet, Nature, 320, 250-252, 1986.

Dahl-Jensen, D., Mosegaard, K., Gundestrup, N., Clow, G. D., Johnsen, S. J., Hansen, A. W., and Balling, N.: Past temperatures directly from the Greenland ice sheet, Science, 282, 268-271, 1998.

Dahl-Jensen, D., Mosegaard, K., Gundestrup, N., Clow, G. D., Johnsen, S. J., Hausen, A. W., and Balling, N.: Past temperatures directly from the Greenland ice sheet, Science, 282, 268-271, 1998.

Dansgaard, W.: Stable isotopes in precipitation, Tellus, 16, 436468, 1964.

Davidson, E. A. and Janssens, I. A.: Temperature sensitivity of soil carbon decomposition and feedbacks to climate change, Nature, 440, 165-173, 2006.

Delmotte, M.: Enregistrements climatiques à Law-Dome: variabilité pour les périodes récentes et pour la déglaciation, Unpub. Thèse de doctorat de troisième cycle thesis, Université Joseph Fourier 300 p, 1997.

Dethloff, K., Rinke, A., Benkel, A., Koltzow, M., Sokolova, E., Saha, S. K., Handorf, D., Dorn, W., Storch, B. R. H. v., Haugen, J. E., Roed, L. P., Roeckner, E., Christensen, J. H., and Stendel, M.: A dynamical link between the Arctic and the global climate system, Geophys. Res. Lett., 33, L03703,doi:10.1029/2005GL025245, 2006.

EPICA-community-members: Eight glacial cycles from an Antarctic ice core, Nature, 429, 623-862, 2004.

Gallée, H., Vanypersele, J. P., Fichefet, T., Marsiat, I., Tricot, C., and Berger, A.: Simulation of the last glacial cycle by a coupled, sectorially averaged climate-ice sheet model. 2. Response to insolation and CO2 variations, J. Geophys. Res., 97, 15713$15740,1992$.

Gallimore, R. G. and Kutzbach, J. E.: Snow cover and sea ice sensitivity to generic changes in Earth orbital parameters, J. Geophys. Res., 100, 1103-1120, 1995.

Genthon, C., Barnola, J. M., Raynaud, D., Lorius, C., Jouzel, J., Barkov, N. I., Korotkevich, Y. S., and Kotlyakov, V. M.: Vostok ice core: climatic response to $\mathrm{CO}_{2}$ and orbital forcing changes over the last climatic cycle, Nature, 329, 414-418, 1987.

Gildor, H. and Tziperman, E.: Sea-ice as the glacial cycles'climate switch: role of seasonal and orbital forcing, Paleoceanography, 15, 605-615, 2000.

Goosse, G. and Fichefet, T.: Importance of ice-ocean interactions for the global ocean circulation a model study, J. Geophys. Res., 104, 23 337-23 355, 1999.

Grachev, A. M. and Severinghaus, J. P.: Determining the thermal diffusion factor for $40 \mathrm{Ar} / 36 \mathrm{Ar}$ in air to aid paleoreconstruction of abrupt climate change, J. Phys. Chem., 107, 4636-4642, 2003.

Guo, Z. C., Bromwhich, D. H., and Hines, K. M.: Modeled antarctic precipitation. Part II: ENSO modulation over West Antarctica, J. Climate, 17, 448-465, 2004.

Harrison, S. P., Braconnot, P., Joussaume, S., Hewitt, C., and Stouffer, R. J.: Comparison of palaeoclimate simulations enhance confidence in models, EOS Transactions, 83, 447-447, 2002.

Hays, J. D., Imbrie, J., and Shackelton, N. J.: Variations in the Earth's orbit: pacemarker of the Ice Ages, Science, 194, 11211132, 1976.

Henderson, G. M. and Slowey, N. C.: Evidence from U-Th dating against Northern Hemisphere forcing of the penultimate deglaciation, Nature, 404, 61-66, 2000.

Holland, M. M. and Bitz, C. M.: Polar amplification of climate change in coupled models, Clim. Dyn., 21, 221-232, 2003.

Houghton, J. T.: Climate change 2001: the Scientific Basis: Cambridge, Cambridge University Press, 896, 2001.

Huber, C., Leuenberger, M., Spahni, R., Flueckiger, J., Schwander, J., Stocker, T. F., Johnsen, S., Landais, A., and Jouzel, J.: Isotope Calibrated Greenland Temperature Record over Marine Isotope 
Stage 3 and its Relation to CH4, Earth Planet. Sci. Lett., 243, 504-519, doi:10.1026j.epsl.2006.01.002, 2006.

Huybers, P.: Early Pleistocene glacial cycles and the integrated summer insolation forcing, Science, 313, 508-511, 2006.

Huybers, P. and Wunsch, C.: Obliquity pacing of the late Pleistocene glacial terminations, Nature, 434, 491-494, 2005.

Imbrie, J. and Imbrie, J. Z.: Modelling the climatic response to orbital variations, Science, 207, 943-953, 1980.

IPCC: Climate Change 2001: Impacts, Adaptation and Vulnerability - Contribution of Working Group II to the Third Assessment Report of IPCC, Cambridge University Press, UK, 1000 p., 2001.

Johnsen, S., Dahl-Jensen, D., Gundestrup, N., Steffenssen, J. P., Clausen, H. B., Miller, H., Masson-Delmotte, V., Sveinbjörnsdottir, A. E., and J., W.: Oxygen isotope and palaeotemperature records from six Greenland ice-core stations: Camp Century, Dye-3, GRIP, GISP2, Renland and NorthGRIP, J. Quaternary Sci., 16, 299-307, 2001.

Joussaume, S., Jouzel, J., and Sadourny, R.: A general circulation model of water isotope cycles in the atmosphere, Nature, 311, 24-29, 1984.

Jouzel, J., Alley, R. B., Cuffey, K. M., Dansgaard, W., Grootes, P., Hoffmann, G., Johnsen, S. J., Koster, R. D., Peel, D., Shuman, C. A., Stievenard, M., Stuiver, M., and White, J.: Validity of the temperature reconstruction from ice cores, J. Geophys. Res., 102, 26471-26 487, 1997.

Jouzel, J. and Merlivat, L.: Deuterium and Oxygen 18 in precipitation: Modelling of the isotopic effects during snow formation: J. Geophys. Res., 89, 11749-11757, 1984.

Jouzel, J., Vimeux, F., Caillon, N., Delaygue, G., Hoffmann, G., Masson-Delmotte, V., and Parrenin, F.: Magnitude of the Isotope/Temperature scaling for interpretation of central Antarctic ice cores, J. Geophys. Res., 108, 1029-1046, 2003.

Kavanaugh, J. L. and Cuffey, K. M.: Space and time variation of $\mathrm{d} 18 \mathrm{O}$ and $\mathrm{dD}$ in Antarctic precipitation revisited, Gobal Biogeochem. Cycles, 17, 1017, doi:10.1029/2002GB001910, 2003.

Khodri, M., Cane, M. A., Kukla, G., Gavin, J., and Braconnot, P.: The impact of precession changes on the Arctic climate during the last interglacial-glacial transition, Earth Planetary Sci. Lett., 236, 285-304, 2005.

Khodri, M., Leclainche, Y., Ramstein, G., Braconnot, P., Marti, O., and Cortijo, E.: Simulating the amplification of orbital forcing by ocean feedbacks in the last glaciation, Nature, 410, 570-574, 2001.

Khodri, M., Ramstein, G., Noblet-Ducoudré, N. D., and Kageyama, M.: Sensitivity of the nothern extratropics hydrological cycle to the changing insolation forcing at 126 and $115 \mathrm{kyr}$ BP, Clim. Dyn., 21, 273-287, 2003.

Kohler, P., Fischer, H., Munhoven, G., and Zeebe, R. E.: Quantitative interpretation of atmospheric carbon records over the last glacial termination, Glob. Biogeochem. Cycles, 19, GB4020, doi:10.1029/2004GB002345, 2005.

Krinner, G. and Genthon, C.: Altitude dependence of the ice sheet surface climate, Geophys. Res. Lett., 26, 2227-2230, 1999.

Krinner, G., Genthon, C., and Jouzel, J.: GCM analysis of local influences on ice core $\delta$ signals, Geophys. Res. Lett., 24, 28252828, 1997.

Krinner, G. and Werner, M.: Impact of precipitation seasonality changes on isotopic signals in polar ice cores, Earth Planet. Sci. Lett., 216, 525-538, 2003.
Krinner, G., Boucher, O., and Balkanski, Y.: Ice-free glacial northern Asia due to dust deposition on snow, Clim. Dyn., 27, 613625, 2006.

Landais, A., Barnola, J. M., Masson-Delmotte, V., Jouzel, J., Chappellaz, J., Caillon, N., Hubert, C., Leuenberger, M., and Johnsen, S.: A continuous record of temperature evolution over a whole sequence of Dansgaard-Oeschger during Marine Isotopic Stage 4 (76 to 62 kyr BP), Geophys. Res. Lett., 31, L22211, doi:10.1029/2004GL021193, 2004.

Landais, A., Caillon, N., Grachev, A., Barnola, J. M., Chappellaz, J., Jouzel, J., Masson-Delmotte, V., and Leuenberger, M.: Quantification of rapid termperature change during DO event 12 and phasing with methane inferred from air isotopic measurements, Earth Planetary Sci. Lett., 225, 221-232, 2004.

Landais, A., Caillon, N., Severinghaus, J., Barnola, J. M., Goujon, C., Jouzel, J., and Masson-Delmotte, V.: Isotopic measurements of air trapped in ice to quantify temperature changes, Comptes Rendus Geoscience, 336, 963-970, 2004.

Landais, A., Chappellaz, J., Delmotte, M., Jouzel, J., Blunier, T., Bourg, C., Caillon, N., Cherrier, S., Malaizé, B., MassonDelmotte, V., Raynaud, D., Schwander, J., and Steffensen, J. P.: A tentative reconstruction of the Greenland Eemian and glacial inception based on gas measurements in the GRIP ice core, J. Geophys. Res., 108, D06103, 1-8, 2003.

Landais, A., Masson-Delmotte, V., Jouzel, J., Raynaud, D., Johnsen, S., Huber, C., Leuenberger, M., Schwander, J., and Minster, B.: The glacial inception recorded in the NorthGRIP Greenland ice core: information from air isotopic measurements, Clim. Dyn., 26, doi:10.1007/s00382-005-0063-y, 2005.

Lang, C., Leuenberger, M., Schwander, J., and Johnsen, J.: $16^{\circ} \mathrm{C}$ rapid temperature variation in central Greenland 70000 years ago, Science, 286, 934-937, 1999.

Lawrence, K. T., Liu, Z. H., and Herbert, T. D.: Evolution of the eastern tropical Pacific through Plio-Pleistocene glaciation, Science, 312, 79-83, 2006.

Lea, D. W.: The $100000-Y r$ cycle in tropical SST, greenhouse forcing, and climate sensitivity, J. Clim., 17, 2170-2179, 2004.

Lhomme, N.: Modelling water isotopes in polar ice sheets, University of Bristish Columbia and Université Joseph Fourier, 172 p., 2004.

Lhomme, N., Clarke, G. K. C., and Ritz, C.: Global budget of water isotopes inferred from polar ice sheets, Geophys. Res. Lett., 32, L20502, doi:10.1029/2005GL023774, 2005.

Liesicki, L. E. and Raymo, M. E.: A Pliocene-Pleistocene stack of 57 globally distributed benthic d18O records, Paleoceanography, 20, PA1003, doi:10.1029/2004PA001071, 2005.

Liu, H.-S.: Insolation changes caused by the combination of amplitude and frequency modulation of the obliquity, J. Geophys. Res., 104, 25 197-25 206, 1999.

Liu, J. P., Curry, J. A., and Hu, Y. Y.: Recent Arctic Sea Ice Variability: Connections to the Arctic Oscillation and the ENSO, Geophys. Res. Lett., 31, L09211, doi:10.1029/2004GL019858, 2004.

Lorius, C. and Merlivat, L.: Distribution of mean surface stable isotope values in East Antarctica. Observed changes with depth in a coastal area, in: Isotopes and impurities in snow and ice, edited by: IAHS, Proceedings of the Grenoble Symposium Aug./Sep. 1975, IAHS Publication, Vienna, IAHS, 125-137, 1977.

Loutre, M. F. and Berger, A.: Marine isotope stage 11 as an analogue for the present interglacial, Global Planet. Change, 36, 
209-217, 2003

Loutre, M. F., Paillard, D., Vimeux, F., and Cortijo, E.: Does mean annual insolation have the potential to change the climate?, Earth Plant. Sci. Lett., 221, 1-14, 2004.

Marshall, J., Kuschner, Y., Battisti, D., Chang, P., Czaja, A., Dickson, R., Hurrell, J., McCartney, M., Saravanan, R., and Visbeck, M.: North Atlantic climate variability: phenomena, impacts and mechanisms, Int. J. Climatology, 21, 1863-1898, 2001.

Martinerie, P., Lipenkov, V. Y., and Raynaud, D.: Air content paleo record in the Vostok ice core (Antarctica): a mixed record of climatic and glaciological parameters, J. Geophys. Res., 99, 10 565-10 576, 1994.

Masson-Delmotte, V., Jouzel, J., Landais, A., Stievenard, M., Johnsen, S. J., White, J. W. C., Sveinbjornsdottir, A., and Fuhrer, K.: Deuterium excess reveals millennial and orbital scale fluctuations of Greenland moisture origin, Science, 309, 118-121, 2005.

Masson-Delmotte, V., Kageyama, M., Braconnot, P., Charbit, S., Krinner, G., Ritz, C., Guilyardi, E., Jouzel, J., Abe-Ouchi, A., Crucifix, M., Gladstone, R. M., Hewitt, C. D., Kitoh, A., Legrande, A., Marti, O., Merkel, U., Motoi, T., Ohgaito, R., Otto-Bliesner, B., Peltier, W. R., Ross, I., Valdes, P. J., Vettoretti, G., Weber, S. L., and Wolk, F.: Past and future polar amplification of climate change: climate model intercomparisons and icecore constraints, Clim. Dyn., 0930-7575, doi:10.1007/s00382005-0081-9, 2006.

Masson-Delmotte, V., Landais, A., Combourieu-Nebout, N., Grafenstein, U. v., Jouzel, J., Caillon, N., Chappellaz, J., DahlJensen, D., Johnsen, S. J., and Stenni, B.: Rapid climate variability during warm and cold periods in polar regions and Europe, C. R. Geosciences, 337, 935-946, 2005.

Masson-Delmotte, V., Landais, A., Stievenard, M., Cattani, O., Falourd, S., Jouzel, J., Johnsen, S. J., Dahl-Jensen, D., Sveinsbjornsdottir, A., White, J. W. C., Popp, T., and Fischer, H.: Holocene climatic changes in Greenland: different deuterium excess signals at GRIP and NorthGRIP, J. Geophys. Res., 110, D14102, doi:10.1029/2004JD005575, 2005.

Masson-Delmotte, V., Stenni, B., and Jouzel, J.: Common millenial scale variability of Antarctic and southern ocean temperatures during the past 5000 years reconstructed from EPICA Dome C ice core, The Holocene, 14, 145-151, 2004.

Masson, V., Vimeux, F., Jouzel, J., Morgan, V., Delmotte, M., Ciais, P., Hammer, C., Johnsen, S., Lipenkov, V. Y., MosleyThompson, E., Petit, J.-R., Steig, E., Stievenard, M., and Vaikmae, R.: Holocene climate variability in Antarctica based on 11 ice cores isotopic records, Quaternary Res., 54, 348-358, 2000.

Medina-Elizalde, M. and Lea, D. W.: The Mid-Pleistocene transition in the tropical Pacific, Science, 310, 1009-1012, 2005.

Mélice, J. L., Coron, A., and Berger, A.: Amplitude and frequency modulations of the Earth's obliquity for the last million years, J. Climate, 14, 1043-1054, 2001.

Merlivat, L. and Jouzel, J.: Global climatic interpretation of the Deuterium-Oxygen 18 relationship for precipitation, J. Geophys. Res., 84, 5029-5033, 1979.

Milankovitch, M. M.: Canon of insolation and the ice-age problem, 484, 1941

Neumann, T. A., Waddington, E. D., Steig, E. J., and Grootes, P. M.: Non-climate influences on stable isotopes at Taylor Mouth, Antarctica, J. Glaciology, 51, 248-258, 2005.
NorthGRIP-community-members: High resolution climate record of the northern hemisphere reaching into last interglacial period, Nature, 431, 147-151, 2004.

Opsteegh, J. D., Haarsma, R. J., Selten, F. M., and Kattenberg, A.: ECBILT: a dynamic alternative to mixed boundary conditions in ocean models, Tellus, 50A, 348-367, 1998.

Paillard, D.: The timing of Pleistocene glaciation from a simple multiple-state climate model, Nature, 391, 378-381, 1998.

Pälike, H. and Shackleton, N. J.: Constraints on astronomical parameters from the geological record for the last $25 \mathrm{Myr}$, Earth Planet. Sci. Lett., 182, 1-14, 2001.

Parrenin, F., Jouzel, J., Waelbroeck, C., Ritz, C., and Barnola, J.-M.: Dating of the Vostok ice core by an inverse method, J. Geophys. Res., 106, 31 837-31 851, 2001.

Parrenin, F. and Paillard, D.: Amplitude and phase of glacial cycles from a conceptual model, Earth Planetary Sci. Lett., 214, 243250, 2004.

Parrenin, F., Rémy, F., Ritz, C., Siegert, M. J., and Jouzel, J.: New modellling of the Vostok ice flow line and implication for the glaciological chronology of the Vostok ice core, J. Geophys. Res., 109, D20102, doi:10.1029/2004JD0044561, 2004.

Peltier, W. R.: Global glacial isostasy and the surface of the iceage Earth: the ICE-5G (VM2) model and GRACE, Annu. Revi. Earth Planet. Sci., 32, 111-149, 2004.

Pépin, L., Raynaud, D., Barnola, J.-M., and Loutre, M. F.: Hemispheric roles of climate forcings during glacial-interglacial transitions as deduced from the Vostok record and LLN-2D model experiments, J. Geophys. Res., 106, 31 885-31 892, 2001.

Petit, J. R., Jouzel, J., Raynaud, D., Barkov, N. I., Barnola, J.-M., Basile, I., Bender, M., Chappellaz, J., Davis, J., Delaygue, G., Delmotte, M., Kotlyakov, V. M., Legrand, M., Lipenkov, V., Lorius, C., Pépin, L., Ritz, C., Saltzman, E., and Stiévenard, M. Climate and Atmospheric History of the Past 420000 years from the Vostok Ice Core, Antarctica, Nature, 399, 429-436, 1999.

Rasmussen, S. O., Andersen, K. K., Svensson, A. M., Steffensen, J. P., Vinther, B. M., Clausen, H. B., Siggaard-Andersen, M.L., Johnsen, S. J., Larsen, L. B., Dahl-Jensen, D., Bigler, M., Röthlisberger, R., Fischer, H., Goto-Azuma, K., Hansson, M. E., and Ruth, U.: A new Greenland ice core chronology for the last glacial termination, J. Geophys. Res., D06102, doi:10.1029/2005JD006079, 2006.

Raymo, M. E. and Nisancioglu, K.: The $41 \mathrm{kyr}$ world: Milankovitch's other unsolved mystery, Paleoceanography, 18, 1011, doi:10.1029/2002PA000791, 2003.

Raynaud, D., Barnola, J. M., Souchez, R., Lorrain, R., Petit, J. R., Duval, P., and Lipenkov, V. Y.: Palaeoclimatology - The record for Marine Isotopic Stage 11, Nature, 436, 39-40, 2005.

Rial, J. A.: Pacemaking the ice ages by frequency modulation of Earth's orbital eccentricity, Science, 285, 564-567, 1999.

Rial, J. A. and Anaclerio, C. A.: Understanding nonlinear responses of the climate system to orbital forcing, Quaternary Sci. Rev., 19, 1709-1722, 2000.

Ritz, C., Rommelaere, V., and Dumas, C.: Modeling the evolution of Antarctic ice sheet over the last 420000 years: implications for altitude changes in the Vostok region, J. Geophys. Res., 106, 31 943-31 964, 2001.

Ruddiman, W. F.: Orbital insolation, ice volume and greenhouse gases, Quaternary Sci. Rev., 15-17, 1597-1629, 2003.

Ruddiman, W. F. and Raymo, M. E.: A methane-based time scale 
for Vostok ice, Quarternary Sci. Rev., 22, 141-155, 2003.

Ruddiman, W.: Cold climate during the closest stage 11 analog to recent millennia, Quaternary Sci. Rev., 24, 1111-1121, 2005.

Schmidt, G. A., Shindell, D. T., and Harder, S.: A note on the relationship between ice core methane concentrations and insolation: Geophys. Res. Lett., 31, L23206, doi:10.1029/2004GL021083, 2004.

Severinghaus, J., Sowers, T., Brook, E. J., Alley, R. B., and Bender, M.: Timing of abrupt climate change at the end of the Younger Dryas interval from thermally fractionated gases in polar ice, Nature, 391, 141-146, 1998.

Severinghaus, J. P. and Brook, E.: Simultaneous tropical-Arctic abrupt climate change at the end of the last glacial period inferred from trapped air in polar ice, Science, 286, 930-934, 1999.

Severinghaus, J. P., Grachev, A., Luz, B., and Caillon, N.: A method for precise measurement of argon 40/36 and krypton/argon ratios in trapped air in polar ice with applications to past firn thickness and abrupt climate change in Greenland and at Siple Dome, Antarctica, Geochim. Cosmochim. Acta, 67, 325-343, 2003.

Shackleton, N. J.: The 100000 year ice-age cycle identified and found to lag temperature, carbon dioxide, and orbital excentricity, Science, 289, 1897-1902, 2000.

Siengenthaler, U., Stocker, T. F., Monnin, E., Lüthi, D., Schwander, J., Stauffer, B., Raynaud, D., Barnola, J.-M., Fischer, H., Masson-Delmotte, V., and Jouzel, J.: Stable carbon cycle-climate relationship during the last Pleistocene, Science, 310, 13131317, 2005.

Solomon, A.: Impact of latent heat release on polar climate, Geophys. Res. Lett., 33, L07716, doi:10.1029/2005GL025607, 2006.

Spahni, R., Chappellaz, J., Stocker, T. F., Loulergue, L., Hausammann, G., Kawamura, K., Flückiger, J., Schwander, J., Raynaud, D., Masson-Delmotte, V., and Jouzel, J.: Variations of atmospheric methane and nitrous oxide during the last 650000 years from Antarctic ice cores, Science, 310, 1317-1321, 2005.

Stenni, B., Jouzel, J., Masson-Delmotte, V., Castellanoc, E., Cattani, O., Falourd, S., Johnsen, S. J., Longinelli, A., Röthlisberger, R., Sachsi, J. P., Selmo, E., Souchez, R., Steffensen, J. P., and Udisti, R.: A high resolution site and source late glacial temperature record derived from the EPICA Dome C isotope records (East Antarctica), Earth Planet. Sci. Lett., 217, 183-195, 2003.

Stenni, B., Masson, V., Johnsen, S. J., Jouzel, J., Longinelli, A., Monnin, E., Roethlisberger, R., and Selmo, E.: An oceanic cold reversal during the last deglaciation, Science, 293, 2074-2077, 2001.
Tuenter, E., Weber, S. L., Hilgen, F. J., and Lourens, L. J.: Sea-ice feedbacks on the climatic response to precession and obliquity forcing: Geophys. Res. Lett., 32, L24704, doi:10.1029/2005GL024122, 2005.

Turner, J.: El Nino-southern oscillation and Antarctica, Int. J. Climatology, 24, 1-31, 2004.

Vettoretti, G. and Peltier, W. R.: Sensitivity of glacial inception to orbital and greenhouse gas climate forcing, Quaternary Sci. Rev., 23, 499-519, 2004.

Vimeux, F., Masson, V., Jouzel, J., Petit, J. R., Steig, E. J., Stievenard, M., Vaikmae, R., and White, J. W. C.: Holocene hydrological cycle changes in the southern hemisphere documented in East Antarctic deuterium excess records, Clim. Dyn., 17, 503513, 2001.

Vimeux, F., Masson, V., Jouzel, J., Stievenard, M., and Petit, J. R.: Glacial-interglacial changes in ocean surface conditions in the Southern Hemisphere, Nature, 398, 410-413, 1999.

Vimeux, F., Masson, V., Delaygue, G., Jouzel, J., Petit, J.-R., and Stievenard, M.: A 420000 year deuterium excess record from East Antarctica: Information on past changes in the origin of precipitation at Vostok, J. Geophys. Res., 106, 31 863-31 873, 2001.

Waelbroeck, C., Labeyrie, L., Michel, E., Duplessy, J. C., McManus, J. F., Lambeck, K., Balbon, E., and Labracherie, M.: Sea level and deep water temperature changes derived from bentic foraminifera isotopic records, Quat. Sci. Rev., 21, 295-305, 2002.

Watanabe, O., Jouzel., J., Johnsen, S., Parrenin, F., Shoji, H., and Yoshida, N.: Homogeneous climate variability across East Antarctica over the past three glacial cycles, Nature, 422, 509$512,2003$.

Werner, M., Heimann, M., and Hoffmann, G.: Isotopic composition and origin of polar precipitation in present and glacial climate simulations, Tellus, 53B, 53-71, 2001.

Wolff, E. W., Fischer, H., Fundel, F., et al.: Southern Ocean seaice extent, productivity and iron flux over the past eight glacial cycles, Nature, 440, 491-496, 2006.

Yiou, P., Vimeux, F., and Jouzel, J.: Deuterium and deuteriumexcess variability over the last four climatic cycles, J. Geophys. Res., 106, 31 875-31 883, 2001.

Yuan, X. J.: ENSO-related impacts on Antarctic sea-ice: a synthesis of phenomenon and mechanisms, Antarctic Science, 16, 415425, 2004.

Yuan, X. J. and Martinson, D. G.: Antarctic sea ice extent variability and its global connectivity, J. Climate, 13, 1697-1717, 2000. 